\title{
Microplastics in the Mediterranean marine environment: a combined bibliometric and systematic analysis to identify current trends and challenges
}

\author{
Marija Papadimitriu and Graeme Allinson * (])
}

\begin{abstract}
In recent decades, the potential toxicological and environmental effects of microplastics (MPs) in the Mediterranean Sea region have received growing attention. The number of studies in this area has increased; however, presently there is no scientometric perspective addressing this topic. The purpose of this study was to identify the intellectual base and research front using the visualization and analysis software, CiteSpace, in combination with a systematic review. We retrieved 150 articles, published in print or online as an early-access article between 1979 and 2020, from the Web of Science with a topic search related to MPs, environment, and uptake by biota. We then analysed synthesized networks of co-authorship (author, institution, country), co-citation (author document, journal) and co-occurring keywords. The annual publication output has trended upwards since 2011, with interest in MP abundance in the Mediterranean Sea particularly high in the past 5 years (2016-2020). Authors based in Italy accounted for $25 \%$ of the total publications, followed by Spain (16\%); but overall publications from Belgium and the Netherlands were more influential. Major research themes identified include the abundance of MPs on beaches, in surface waters, sediments and biota. Secondary microplastics, such fibres and fragments, of a wide range of sizes and chemical composition were dominant in scientific reports, albeit citizen science collection of plastic resin pellets for International Pellet Watch suggests such primary MPs are also widespread, even if their numerical abundance from such collections is unclear. Few studies reported chemical contamination of MPs in the Mediterranean albeit a significant amount of information on the level of chemical contamination of plastic resin pellets is available on the International Pellet Watch website.
\end{abstract}

Keywords: Microplastic, beach, sediment, marine waters, biota

\section{Introduction}

Although largely considered to be a twentieth Century phenomenon, the first synthetic polymers based on nitrocellulose were developed in the nineteenth Century. However, plastic materials were enthusiastically embraced by both industry and the community in the first half of the twentieth Century as new types (such as

*Correspondence: graeme.allinson@rmit.edu.au The Plastics Lab, School of Science, RMIT University, 124 La Trobe St, Melbourne, Victoria 3001, Australia polyamides (PA), polycarbide (PC), polyurethanes (PU), polyvinylchloride (PVC), polyethylene (PE), polypropylene (PP), polyethylene terephthalate (PET) and polystyrene (PS)) were invented and new uses found for them. As of 2018, worldwide plastic production is estimated to be more than 350 million tonnes, with plastic production in Europe in excess of 60 million tonnes [140]. There are many well-recognised benefits that plastic materials have brought society. For instance, in developed nations around one third of the plastic consumed is used in building construction and other infrastructure, e.g., piping 
and other plumbing products, and PS insulation, while a further third is used in plastic packaging and wrapping, which protects and preserves consumables and other goods, while reducing weight in transportation, which saves fuel and reduces greenhouse gas emissions. Many of the mass-produced modern plastics are based on saturated hydrocarbon polymers, which contributes to their chemical and biological stability [84]. However, that relative stability leads to persistence of these plastics in the environment.

Plastic debris in the terrestrial environment originating from domestic, urban business and industrial activities, may be transported by stormwater flows into local streams, from whence it may be transported into rivers and ultimately the marine environment. Plastic materials may also enter the oceans directly in the discharge from the wastewater treatment systems of coastal communities, or indirectly via estuaries where wastewater is discharged into rivers [89]. Other sources include materials lost by professional maritime activities and recreational fishing, debris dumped by commercial, cruise or private ships, and windblown transport from the land. Lebreton et al. [99] suggested that the Mediterranean Sea is a marine environment with one of the highest levels of plastic pollution worldwide, as was to be expected for a semi-enclosed sea surrounded by a vibrant coastline with few outlets [55]. In that context, it has recently been estimated that the Mediterranean Sea receives between 150 and 610 thousand tonnes of plastics each year (average 229 thousand tonnes), $94 \%$ of which is microplastic debris and 6\% microplastics [27]. Egypt, Italy, and Turkey are considered to be the top three emitters of plastic, with hotspots associated with major rivers and/or near large urban areas.

Plastic particles that have a density lower than seawater (most synthetic polymers) float on the water's surface [102], while particles with higher density will sink and be deposited on the seafloor. However, buoyant particles may also sink as a result of biofouling and particle adherence [155]. Beaches are a deposition point for floating debris deposited by waves and are also capable of accumulating sinking plastic particles [88]. Although there is still some debate as to what is the minimum size particles should be to be classified as MPs, there is a general consensus that they are pieces of plastic with a diameter smaller than $5 \mathrm{~mm}$. Microplastics are further defined as being primary MPs, which includes such things as plastic resin pellets, the raw materials for plastic manufacture, and small particles manufactured for use in cleansing or beauty products (microbeads), in textile (microfibres); secondary MPs are those MPs that result from the breakdown of larger pieces of plastics by physical and chemical degradation, or biological decomposition [102].
The extent and mechanisms of MPs impacts on the environment are still being established. It is known the first report on MPs in the Mediterranean Sea was by Shiber [137], although more detailed research did not begin to be published until the early 2000s. Microplastics have now been observed in the water column, in marine sediments, on beaches and in biota in the region. Moreover, while the ecotoxicological hazard of microplastics due to simple mechanical and physical damage induced by MPs is known, other direct or indirect effects may occur when the very smallest particles travel through the food chain [11], living organisms are exposed to toxic chemicals in/sorbed to MPs [124], and new geological materials ('plasticrusts') are created by sea waves smashing plastic debris against rocks [64]. In that context, the aim of this study was to identify the peer-reviewed literature that presents the environmental levels of MPs in the marine environment of Mediterranean basin, including the Black Sea. The search to identify relevant publications allowed for the construction of a database with the references on research carried out on microplastics in the Mediterranean Sea since 1979, when the first scientific publications related to the subject studied appeared. Thereafter we sought to answer the following questions: (i) how has the scientific research on microplastics evolved in the Mediterranean Sea basin in recent years?; (ii) in which journals were these studies published?; (iii) which were the educational and research institutes involved; (iv) are there collaborative networks among research institutions?; (v) are there any gender biases in publication; (vi) what were the findings of microplastic surveys?; and (vii) what are the main knowledge gaps to inform and guide future work?

\section{Methods}

\section{Data collection}

A search to identify relevant publications was conducted using the SCOPUS and Web of Science core collection databases on 21 September 2020. The search was limited to published original, peer-reviewed research articles written in English. The search terms, "(microplastic OR nanoplastic) AND Mediterranean AND (water OR sediment OR beach OR fish OR mussel OR whale OR invertebrate)" were applied to article Title, Abstract, or Keywords. Primary documents identified by these two searches were downloaded from publishers' websites to the extent that RMIT's Library access allowed. To remove duplicates, the bibliographic details of all retrieved studies were manually collated in Excel with duplicates deleted from the spreadsheet (Supplementary Information Fig. S 1). Then, an initial screening of article content was undertaken to assess relevance for inclusion in the 


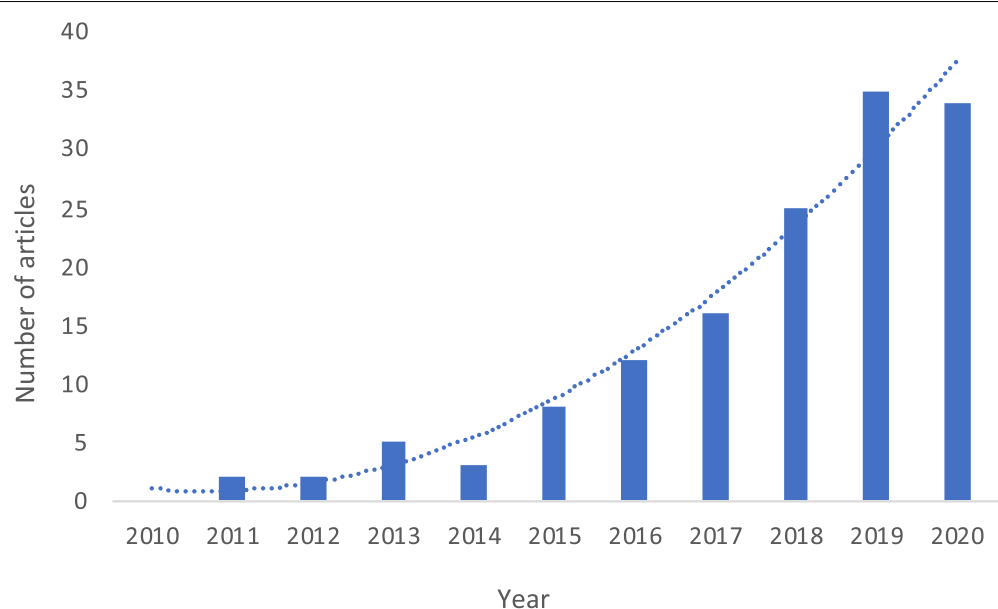

Fig. 1 Number of peer-reviewed articles on microplastic particles in the Mediterranean Sea basin published per year (2010-2020 data only). The line depicts the relationship between the number of articles and year. This figure only includes articles that met the inclusion criteria of this review

review. The inclusion criteria applied for the subsequent review and analysis were:

1. Article written in English, was published in a recognized peer-reviewed journal, and described primary research e.g., was not a review that had been misidentified. Technical reports, course monographs, academic dissertations and theses, and abstracts or full papers of conference proceedings were not considered.

2. Article reported micro- or nano- plastics detection levels in the marine environment of the Mediterranean Sea basin, including the Black Sea; studies were included even if their primary focus was macroplastic or other debris provided there was data on microplastics; studies that focused on sources in riverine catchments, or riverine levels, and measurements in estuaries or enclosed lagoons/harbours were not included in the scientometric review.

3. Article reported environmental uptake by biota, i.e., not a laboratory uptake experiment or modelling.

A more detailed screening of article content was then undertaken which resulted in an additional 84 papers being identified from citations within the articles (Fig. S1). Thereafter, additional relevant articles were obtained as/when identified through journal alerts.

Once articles were selected, study characteristics and data items were extracted from article content (Table S1) and managed in Excel. For instance, we used Bendels et al. [19] method to define the proportion of female authorships (FAP), this being the quotient between the number of female authorships and the total sum of male and female authorships $(\mathrm{F} /(\mathrm{F}+\mathrm{M})$. Bendels et al. [19] female-to-male authorship odds ratio (FAOR) for 1st authorship $\left(\mathrm{FAOR}_{\text {First }}=\right.$ FemaleOdds $_{\text {First }} /$ MaleOdds $\left._{\text {First }}\right)$ was also calculated for the same 166 articles, with FemaleOdds $_{\text {First }}=$ Female $_{\text {NumberFirst }} / \quad\left(\right.$ Female $_{\text {NumberCoauthor }}+$ Female $\left._{\text {NumberLast }}\right)$ and MaleOdds First $=$ Male $_{\text {NumberFirst }} /$ $\left(\right.$ Male $_{\text {umberCoauthor }}+$ Male $\left._{\text {NumberLast }}\right)$. The female-to-male authorship odds ratio for last authorship $\left(\mathrm{FAOR}_{\text {Last }}\right)$ was calculated using data where there are three or more authors on a paper.

\section{Scientometric analysis}

Network analyses and visualizations were performed on 146 articles with CiteSpace (version 5.7.R3), which is an open source bibliometrics software developed by Chen [40]. All bar 4 WoS database records from 1979 to 2020 were successfully converted to a CiteSpace-friendly format. The parameters used to synthesize each final stable network were node selection g-index $(k=50)$, time slicing (years per slice) $=1$, pruning (pathfinder, pruning sliced networks), term source (title, abstract, author keywords, and keywords plus), links (retaining factor $=10$ ), and visualization (cluster view-static and show merged network). Cluster labelling was conducted automatically using the log-likelihood ratio (LLR) function.

The modularity $\mathrm{Q}$ index [112] and average silhouette score [127] were used to measure the structural quality of the network. The modularity, Q, ranging from 0 to 1 , measures the degree to which a network can be separated into independent components $[40,43]$. The silhouette metric, ranging from -1 to 1 , reflects a cluster's degree of homogeneity and estimates the uncertainty involved in interpreting a cluster. The connectivity of the network was measured by betweenness centrality (ranging from 0 to 1 ) for each node in the network [74]. Temporal 
properties of the networks and clusters were evaluated by burst strength [92] and sigma score $(\Sigma)$ [42]. High burst strength indicates a strong and sudden surge of interest in a particular theme. Sigma $(\Sigma)$ is a measure of scientific novelty, derived from burst strength and betweenness centrality.

\section{Results and Discussion \\ Publication trends}

The first publications on microplastics in the coastal marine environment appeared in the 1970s, discussing pollution from primary plastic sources such as resin pellets in water [37] and on beaches [86]. The first scientific articles specifically dealing with MPs in water, marine sediments and on beaches in the Mediterranean Sea basin were published in 1980 (Morris), 2013 (van Cauwenberghe et al.) and 1979 (Shiber), respectively. Our selection process identified 150 articles (1979-2020) that described levels of MPs in the one or more compartments of the Mediterranean Sea, of which 45 reported levels in water, 24 in marine sediments, 30 on beaches and 56 in field collected biota. Articles were predominantly published in journals with primary discipline designations of agricultural and biological science (59\%), and environmental science (29\%). There was a strong positive correlation between the numbers of articles and years published in the period 2010-2020 (Fig. 1; $\mathrm{r}^{2}=0.95$ ) which supports the general impression of growing interest in MPs research since 2010.

\section{Country, institution and authors of origin Country of authorship}

Authors were based across 35 countries (Fig. 2), within which there were 4 main clusters. The main countries where authors were based include Italy $(n=55,25.1 \%)$, Spain $(n=36,16.4 \%)$, France $(n=20,9.3 \%)$, and Turkey and Greece $(n=13,6.0 \%)$. Overall, $17(65 \%)$ of the 26 countries surrounding the Mediterranean and Black Seas were represented in the authorship records. Most of the authors were based in developed countries $(98.5 \%)$ with only a small number in developing countries $(1.1 \%)$ or countries in transition $(0.4 \%$; as defined by [147]). The network of co-authors' countries consisted of 35 nodes (Fig. 2; $E=70$, density $=0.1176$ ). The five highest ranked countries by betweenness centrality were Italy $($ centrality $=0.70)$, France $($ centrality $=0.53)$, Greece $\quad($ centrality $=0.24)$, Spain $\quad($ centrality $=0.17)$, and England (centrality $=0.12$ ). In comparison, the top ranked countries by burst strength were Belgium (strength $=3.49)$, the Netherlands $($ strength $=0.69$ ),
Slovenia (strength $=0.54$ ) and Norway (strength $=0.52$ ). This signifies that these latter countries have had a more important role in collaborations in the field of MPs than the other countries.

\section{Organisation}

An organisational analysis was used to reveal academic collaborations at the level of institutions (Fig. 3). The network consisted of 210 nodes ( $E=448$, density $=0.0204)$, and was divided into 39 clusters (modularity $\mathrm{Q}=0.3766$, average silhouette $=0.9401$ ). The institution co-authorship was dominated by six interlinked networks that together form one large sub-network that represented 69\% (nodes $=146$ ) of the whole network. The top 5 organisations with the largest research output were CNR (Consiglio Nazionalle delle Recherche), Italy (records $=15,7.1 \%$ ), the Bioscience Research Center, Italy (11, 5.2\%), the University of Messina, Italy (10, 4.8\%), the University of Siena $(9,4.2 \%)$ and the University of Barcelona, Spain and the Centro Oceanografico de Baleares, Spain (8, $3.8 \%)$.

Institutions with higher betweenness centrality are instrumental in facilitating collaborations across several countries. The largest sub-network was centred on CNR (Fig. 4), the highest ranked organisation by betweenness centrality, and featured strong links to organisations in the eastern Mediterranean, and an early network focussed on linking the Italian National Institute for Environmental Protection and Research (ISPRA), the University of Messina, Italy and the University of Siena, Italy. Another older network in this region links the Institute of Water Slovenian Republic with the fifth highest ranked organisation based on burst strength, the University of Ghent (strength $=1.28$ ). The three smaller (mid-size) sub-networks clearly identifiable were collaborations between institutions based in one or two countries. The earliest small sub-network is comprised of institutions based in Belgium and France (University of Liege, strength $=1.66$; IFREMER, strength $=0.65$ ). More recent sub-networks are comprised of institutions based in France and Spain e.g., linking the University of Barcelona, the University of Cadiz, and the University of Southern Brittany. There was also one very small, isolated network linking three organisations without collaborative links to any other organisation in the region. Nodes in the network were connected by links of varying thickness, which suggests varying degrees of intensity of inter-cooperation among them. Institutions in eastern Mediterranean tended to collaborate more with those based in Italy, whereas those in the western Mediterranean tended to collaborate with organizations in that region. Links between institutions in the two halves 
Citespace, v. 5.7233 (64-bit)

lanuary 11,2021 1:52:39 PM AEDT

WoS: /Users/graemeallinson/Documents/Work (citespace)/Med MPs/data/data Wos unique

Timespan: 2011-2020 (Slice Length $=1$ )

Network $N=35, E=70$ (Density $=0.1176$ )

Largest CC:31 (88\%)

Nodes Labeled: $1.0 \%$

Pruning: None

\section{TURKEY}

\section{CROATIA}

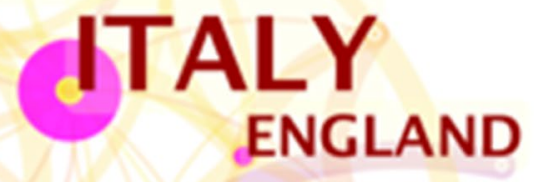

SLOVENIA GREECE

\section{SPAIRgRTUGaL SPAIN}

\section{TUNISIA}

Fig. 2 Distribution of the number of records attributed to authors based in each country: (threshold $=5$, modularity $Q=0.1985$, average silhouette $=0.8744$ ). Node size signifies the number of papers that originated from the country. Distance between nodes and link thickness indicates the level of collaboration, link colour indicates earliest period of establishment (purple, oldest; yellow, most recent). Nodes without labels were below the threshold

of the Mediterranean basin have formed, albeit most have been initiated in the last 5 years.

\section{Authorship}

The five most prolific authors of the articles related to MPs in the Mediterranean environment (1979-2020) are Guerranti $\mathrm{C}$ and Renzi $\mathrm{M}$ (records $=11,7.6 \%$ ), Fossi $\mathrm{MC}$ and Blašković A (8,5.5\%), and Romeo T (6, 4.2\%). The remaining authors each contributed $\leq 5$ records, with more than half of the authors contributing to only 1 record.

The author analysis was used to reveal academic collaborations among authors. The network consisted of 


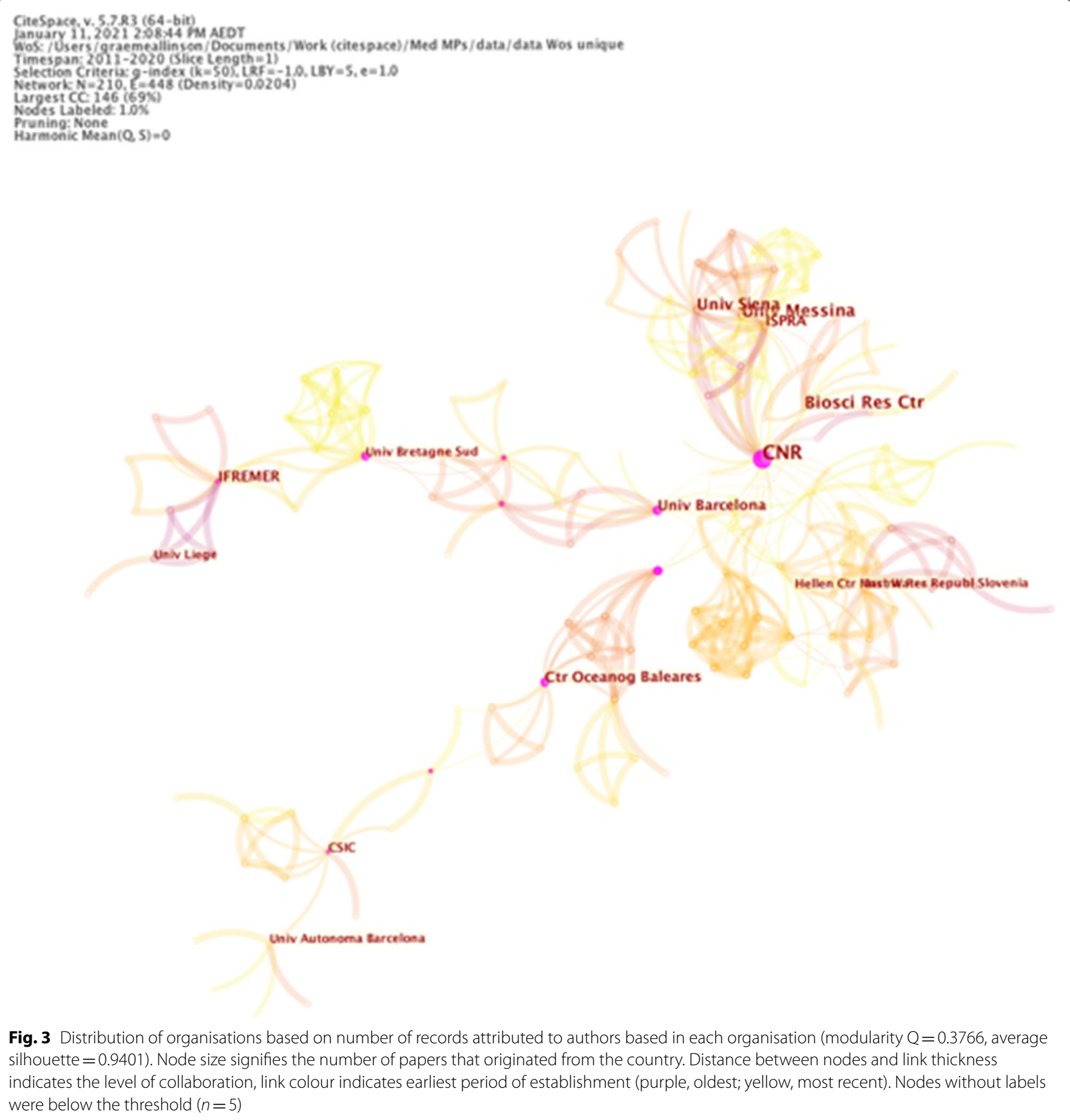

329 nodes $(E=1036$, density $=0.0192)$, and was divided into 57 clusters. The largest sub-network contained 92 nodes and accounted for $27 \%$ of the overall network. Overall, the network was centred around six nodes, (Fig. 4) with many very isolated sub networks. There were no nodes with a betweenness centrality $>0.06$. This suggests that the authors tended to cooperate in small teams, and collaboration between teams was limited. Given that the analysis covers oceanographic surveys of the water column, marine sediment surveys, beach and biota surveys this analysis is consistent with each group having a specific research speciality that does not necessitate co-collaboration.

Publications that undergo a sudden surge in interest give individual authors a high burst strength. The author with the strongest burst strength was Fastelli P (Table 1), who has published on MPs levels in the water column and marine sediments (e.g., [68]). Other 


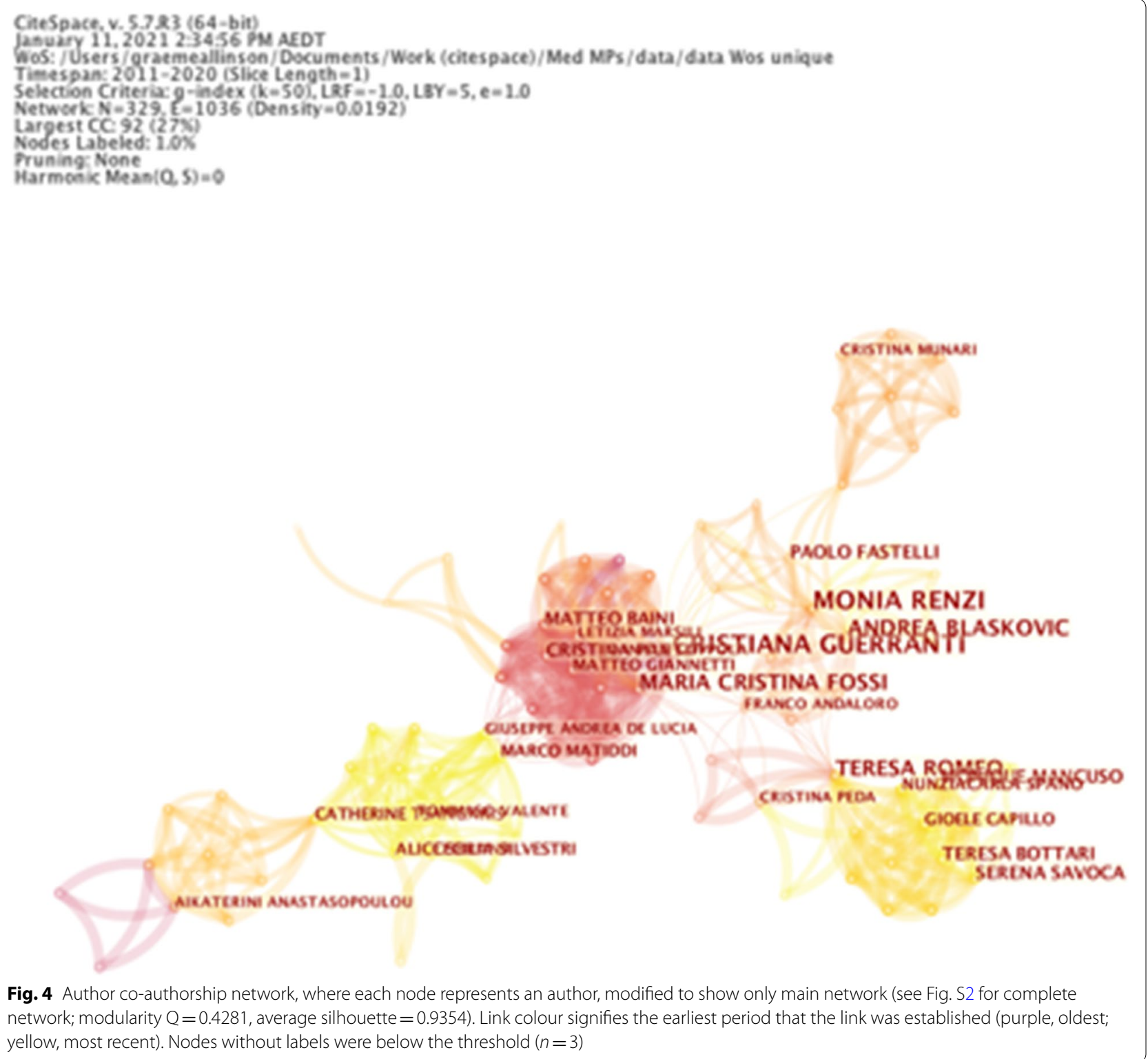

influential authors also reported on concentration of plastic in cetaceans (e.g., [73]), and in fish (e.g., [50]).

\section{Influential Authors, Documents, and Journals: Co-citation} analyses

Author co-citation analysis (ACA)

The author co-citation analysis (ACA) is used to obtain the distribution of highly cited authors in a research field [41]. It can also reveal the research focus of similar authors, the distribution of their subject areas through the co-citation network and identify influential authors. The ACA network contained 618 nodes in one large network divided into 7 co-citation clusters $(E=35,289$, density $=0.1848$, modularity $\mathrm{Q}=0.0688$, average silhouette $=0.6885)$ The top five most cited authors in the field of Mediterranean MPs research were Galgani F (citations $n=78)$, Cozar A $(n=77)$, Cole $\mathrm{M}(n=71)$, Lusher $\mathrm{AL}$ and Eriksen M $(n=70)$. The first two of these authors were among the first to report on detection of MPs in the Mediterranean environment (e.g., [51, 55]) with the remaining authors reporting on MPs in other marine systems.

The authors ranked highly by burst strength published on the topics of microplastics in the marine environment, albeit not with specific focus on the Mediterranean. The 
Table 1 Top 10 cited authors ordered by burst strength during period of analysis (2011-2020)

\begin{tabular}{lcccc}
\hline Authors & \multicolumn{3}{c}{ Burst } \\
\cline { 2 - 5 } & Strength & Begins & Ends & $\mathbf{2 0 1 1 - 2 0 2 0}$ \\
\hline P Fastelli & 2.14 & $\mathbf{2 0 1 7}$ & 2018 & \\
MC Fossi & 1.52 & $\mathbf{2 0 1 4}$ & 2016 & \\
F Andaloro & 1.52 & $\mathbf{2 0 1 5}$ & 2016 & \\
F Collard & 1.41 & $\mathbf{2 0 1 4}$ & 2015 & \\
C Guerranti & 1.40 & $\mathbf{2 0 1 6}$ & 2018 & \\
M Renzi & 1.22 & $\mathbf{2 0 1 7}$ & 2018 & \\
F Regoli & 1.13 & $\mathbf{2 0 1 5}$ & 2017 & \\
M Giannetti & 1.10 & $\mathbf{2 0 1 4}$ & 2016 & \\
E Marti & 1.01 & $\mathbf{2 0 1 5}$ & 2016 & \\
F Rubegni & 1.01 & $\mathbf{2 0 1 5}$ & 2016 & \\
\hline
\end{tabular}

author with the strongest burst was Moore CJ (Table 2), reported on concentration of plastic in the Pacific [108]. Other influential authors include Teuton EL, who reported the potential for plastics to transport hydrophobic contaminants [143], and Morét-Ferguson S, who reported the size, mass, and composition of plastic debris in the western North Atlantic Ocean [109], and Boerger $\mathrm{CM}$ who published on plastic ingestion by planktivorous fishes in the North Pacific [25].

\section{Journal co-citation analysis (JCA)}

The 146 publications on microplastics in the Mediterranean environment examined scientometrically occurred across 32 different journals. The top five journals responsible for publishing most of the identified articles were: Marine Pollution Bulletin (articles $n=68 ; 46.3 \%$ ), Environmental Pollution $(n=19,12.9 \%)$, Science of the Total Environment $(n=9,6.1 \%)$, Marine Environmental Research $(n=6,4.1 \%)$, and jointly Environmental Science and Pollution Research and Estuarine, Coastal and Shelf Science $(n=5,3.4 \%)$.

A Journal Co-citation Analysis (JCA) was performed on the 2010-2020 dataset to identify the most influential journals since the JCA can provide an improved appraisal of a journal's relevance and influence on a research field compared to considering only the number of publications [154]. The single, large network contained 358 nodes $(\mathrm{E}=11,063$, density $=0.1731)$, divided into 6 overlapping

Table 2 Top 10 co-cited authors ordered by burst strength in the analysis period (2011-2020)

\begin{tabular}{lccll}
\hline Cited Author & \multicolumn{3}{c}{ Burst } \\
\cline { 2 - 5 } & Strength & Begin & End & 2011 - 2020 \\
\hline CJ Moore & 4.59 & $\mathbf{2 0 1 2}$ & 2016 & \\
EL Teuten & 4.53 & $\mathbf{2 0 1 2}$ & 2016 & \\
S Morét-Ferguson & 4.05 & $\mathbf{2 0 1 6}$ & 2018 & \\
MR Gregory & 3.91 & $\mathbf{2 0 1 1}$ & 2015 & \\
CM Boerger & 3.65 & $\mathbf{2 0 1 4}$ & 2016 & \\
KL Law & 3.58 & $\mathbf{2 0 1 2}$ & 2016 & \\
MJ Doyle & 3.16 & $\mathbf{2 0 1 2}$ & 2015 & \\
P Davison & 3.09 & $\mathbf{2 0 1 3}$ & 2016 & \\
RC Thompson & 3.01 & $\mathbf{2 0 1 2}$ & 2015 & \\
T Kukulka & 2.78 & $\mathbf{2 0 1 4}$ & 2016 & \\
\hline
\end{tabular}


co-citation clusters. The network was moderately structured $(\mathrm{Q}=0.1769)$, and clusters had acceptable heterogeneity (average silhouette $=0.6118$ ). None of the top 10 journals with the highest frequency in the bibliometric analysis (Marine Pollution Bulletin $(n=142)$, Environmental Pollution $(n=133)$, Marine Environmental Research $(n=127)$, Environmental Science \& Technology $(n=124)$, PLOS One $(n=98)$, Science $(n=92)$, Philosophical Transactions of the Royal Society B $(n=91)$, Science Reports $(n=90)$, Science of the Total Environment $(n=72)$ or Estuarine, Coastal and Shelf Science $(n=67))$ appeared in the top ten journals ranked by burst strength (Table 3). This suggests that the scope of the journals with the strongest citation bursts tended to be related to mechanistic studies, whereas the scope of journals with the highest citation frequency tended to be related to marine environment and environmental science.

\section{Document co-citation analysis (DCA)}

The document co-citation analysis (DCA) identifies research clusters with common themes linked via document co-citations $[43,138]$. The synthesized DCA network contained 607 nodes $(E=22,317$, density $=0.1213)$ and was divided into 6 co-citation clusters. The modularity Q of the network is 0.1057 , which indicates a loosely structured network, and the average silhouette was 0.7630 , which suggests a good degree of homogeneity for clusters overall. The top five documents most frequently returned by this analysis were [55]; $n=55)$ [89]; $n=45),[141] ; n=44),[65] ; n=43)$, and [5]; $n=39$ ). Of these documents only that by Cozar et al. [55], Suaria et al. [141] and Alomar et al. [5] specifically reported on detection of MPs in the
Mediterranean environment with the remaining documents are reviews of the levels of MPs in other marine systems, or methods for the measurement thereof.

The research described in publications with high burst strength is influential and often associated with major research milestones that are pivotal to the development of the field $[9,44]$. In that context, only two of the top 10 documents by burst strength (Table 4) were co-authored by one of the top 10 cited authors in the network (Table 1), specifically the papers co-authored by Fossi et al. [72] and Collignon et al. [51], the latter with F Collard. However, half the documents include one of the top 10 co-cited authors based on burst strength, RC Thompson (Table 4).

The network is divided into 6 co-citation clusters. The silhouette values for the 6 clusters were in the range of 0.68-0.99, which indicates a high level of homogeneity for these clusters and that cluster labelling is reflecting cluster content [43]. These clusters are labelled by index terms from their own citers. In that context, cluster labelling and identification of representative terms was conducted automatically using the log-likelihood ratio (LLR) function [63]. Representative terms are selected from noun-phrases in the titles and abstracts of citing articles, ranked by the LLR algorithm, and the topranked term is designated as the cluster label $[43,44]$. The longest clusters depicted in the timeline visualization (Fig. 5) were cluster \#2, automatically labelled as 'western Sardinian coast', followed by cluster \#0 boops boop, and cluster \#1 adriatic sea. The most recently initiated, and current cluster was cluster \#0 boops boop.

The largest cluster (\#0) was labelled as 'boops boop' by LLR, although the cluster's theme based on the major

Table 3 Top 10 journals ordered by burst strength

\begin{tabular}{lcccc}
\hline Cited Journal & \multicolumn{3}{c}{ Burst } \\
\cline { 2 - 5 } & Strength & Begin & End & $\mathbf{2 0 1 1 - 2 0 2 0}$ \\
\hline NATURE & 3.27 & $\mathbf{2 0 1 2}$ & 2016 & \\
J COASTAL RES & 2.52 & $\mathbf{2 0 1 2}$ & 2014 & \\
GEOPHYS RES LETT & 2.05 & $\mathbf{2 0 1 4}$ & 2016 & \\
J FISH BIOL & 2.03 & $\mathbf{2 0 1 5}$ & 2016 & \\
J MAR BIOL ASSOC UK & 2.00 & $\mathbf{2 0 1 5}$ & 2016 & \\
ENVIRON TECHNOL & 1.82 & $\mathbf{2 0 1 2}$ & 2014 & \\
CHEMOSPHERE & 1.61 & $\mathbf{2 0 1 1}$ & 2013 & \\
LIMNOL OCEANOGR-METH & 1.28 & $\mathbf{2 0 1 3}$ & 2014 & \\
AMBIO & 1.28 & $\mathbf{2 0 1 3}$ & 2015 & \\
MAR BIOL & 1.32 & $\mathbf{2 0 1 4}$ & 2015 & \\
\hline
\end{tabular}


Table 4 Top 10 cited documents ordered by burst strength (2011-2020)

\begin{tabular}{|c|c|c|c|c|}
\hline \multirow[t]{2}{*}{ Reference } & \multicolumn{4}{|l|}{ Burst } \\
\hline & Strength & Begin & End & 2011-2020 \\
\hline Andrady [7] & 7.22 & 2013 & 2016 & \\
\hline Collignon et al. [51] & 7.01 & 2012 & 2017 & 1 \\
\hline Lusher et al. (2013) & 6.57 & 2015 & 2018 & \\
\hline Fossi et al. [72] & 6.49 & 2014 & 2017 & \\
\hline Claessens et al. [48] & 5.77 & 2013 & 2016 & \\
\hline Boerger et al. [25] & 5.65 & 2012 & 2015 & \\
\hline Hidalgo-Ruz et al. [88] & 5.52 & 2012 & 2017 & 1 \\
\hline Browne et al. [29] & 5.29 & 2013 & 2016 & \\
\hline Wright et al. (2013) & 5.17 & 2015 & 2018 & 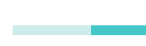 \\
\hline Barnes et al. [15] & 5.00 & 2012 & 2014 & 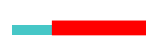 \\
\hline
\end{tabular}

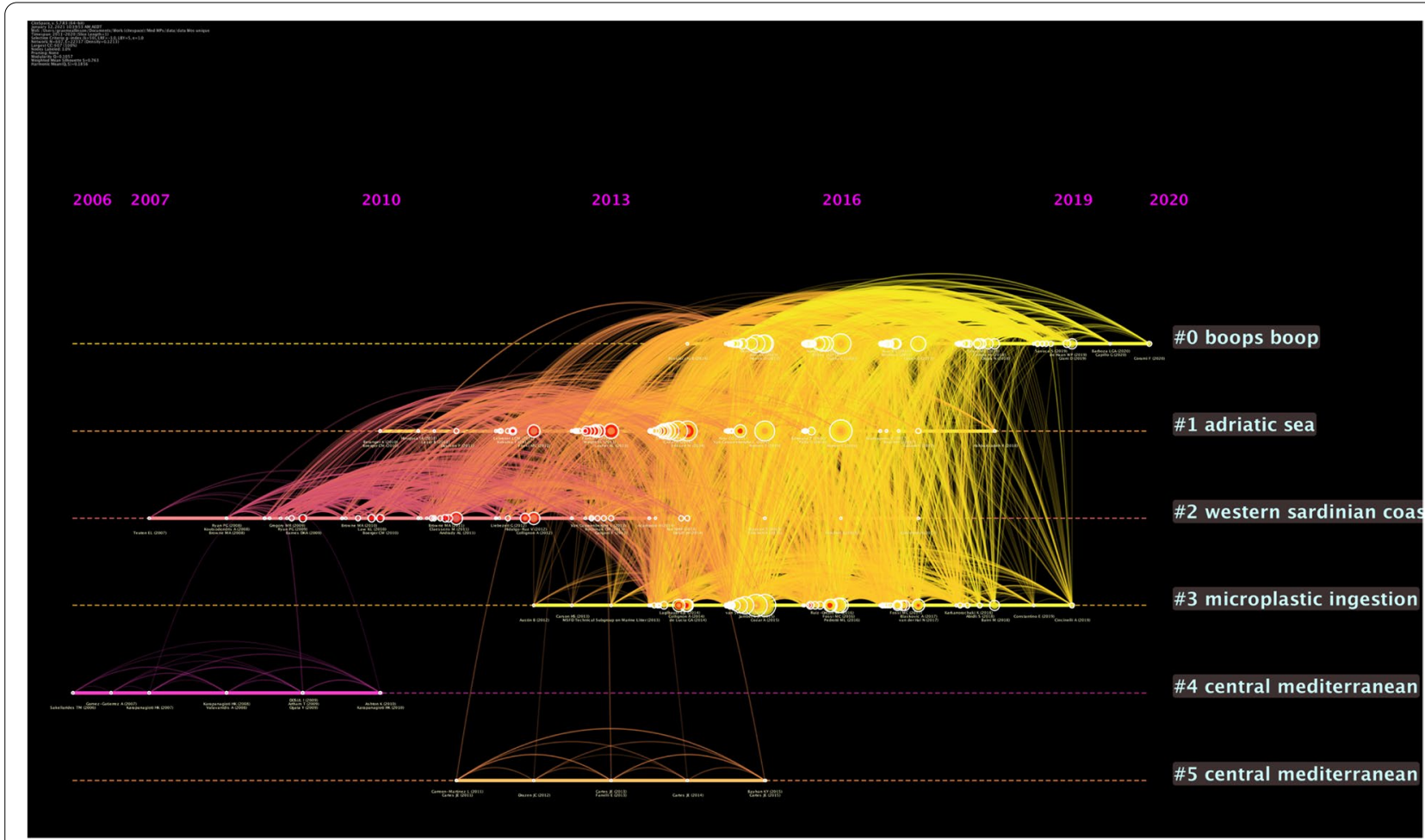

Fig. 5 Document Co-citation Analysis visualised as a timeline with automatically generated cluster labels (threshold by burst $=5$ ). Nodes represent cited documents labelled with first author and year of publication. Nodes below the threshold were not labelled. The colour of co-citation links is indicative of the transition of research focus over time, with the most recently established links in yellow. Modularity $Q=0.1057$, average silhouette $=0.7630$.

index terms was more broadly related to deep-sea environment, flagship species, macrodebris, and floating plastic pollution with a focus on ingestion by organisms. This cluster contained articles with strong citation bursts, albeit that, as noted earlier, most of the top ten articles by burst strength concerned studies outside the Mediterranean Sea basin. In that context, the top Mediterranean
Sea focussed article by burst strength was titled, "Neustonic microplastic and zooplankton in the North Western Mediterranean Sea," [51]. The next two highest article by burst strength were titled, "Are baleen whales exposed to the threat of microplastics? A case study of the Mediterranean fin whale (Balaenoptera physalus)" [72], and "Microplastic particles in sediments of Lagoon of Venice, 
Italy: First observations on occurrence, spatial patterns and identification" [151]. Such studies are pivotal in that they played a key role highlighting the importance of MPs in the Mediterranean Sea basin, whereas previously the major focus of MPs research was elsewhere.

\section{Are there any gender biases in authorship?}

It is generally understood that representation of women in academia drops off as they progress through the system, e.g., even where females represent at least $50 \%$ of undergraduate cohorts in a discipline, the proportion of women is reduced at each successive tier, with the greatest discrepancy at the highest ranks [19]. Moreover, the publication of peer reviewed journal articles is often used to project potential in initial hiring and subsequent internal organisational promotion processes. In that context, the position of an author in the authorship list is important in many research areas, including environmental science, albeit for reasons that bear no relation to the physical and intellectual contributions of the various authors to the article's content. In the environmental sciences, including marine sciences, it is commonly understood that the first author indicates the person who did most of the work that made the paper possible (often, but not always, a research student or non-tenured research fellow), with the last author being the person whose work or role made the study possible (typically, but not always, project leader or supervisor). Consequently, authorship prestige follows a ranked order with the higher reputations being that of first and last authorships; co-authorships, i.e., all authorships listed between the first and last authors, have lower prestige, especially in long authorship listings. First authorship, in particular, is viewed a measure of academic success in early career researchers, with 'last author' an important measure of success for established researchers, e.g., for grant funding success.

To assess whether there are any gender biases/barriers, we first estimated the gender distribution in articles where authors were listed using only initials, which Bendels et al. [19] suggest may itself be a strategy employed by some women to pre-empt perceived and/or actual gender bias in the publication process. In this context, there are 23 articles in our database in which authors are recognised only using initials. Of the 106 unique authors in those papers, $53 \%$ are female, $46 \%$ male, and $1 \%$ unassignable. It is worth noting that few of those authors only ever used initials on the papers in our database, most use their given,surname on other papers, suggesting initialization is not a common strategy amongst this group of female researchers to try to avoid real or perceived gender bias in publication.

Given the importance of first author publications for hiring and advancement, we also sought to quantify whether women are underrepresented as first authors in the studies of microplastics in the Mediterranean basin in our database. In that context, there are 596 individual author names across the papers reviewed, of which 296 (49.7\%) were female names, 296 (49.7\%) were male with 4 authors $(0.7 \%)$ whose gender could not be attributed. Of the 166 articles (1979 - April 2021), five of articles were single author papers, all authored by men; two articles were authored by a person whose given name, and hence gender, could not be ascertained. Using Bendels et al. [19] approach, the FAP for our database is 0.64. In other words, women are $64 \%$ of all 1st authors in our database. Bendels et al. [19] FAOR for 1st authorship (FAOR $\left.{ }_{\text {First }}\right)$ for women in our database is 1.82 . Given the rapid increase in publications post 2015, we assessed whether the FAP changed over time, but found that there was only a weak positive correlation for female 1st authorship $\left(r^{2}=0.32\right)$. Analysis of last authorships also provides for some preliminary conclusions regarding the academic status of women in the organisations undertaking the studies. In that context, the $\mathrm{FAP}_{\text {Last }}$ for our database is 0.48 , i.e., women are $48 \%$ of last authors. The female-tomale authorship odds ratio for last authorship $\left(\mathrm{FAOR}_{\text {Last }}\right)$ was 1.84. Overall, the data suggests that women studying microplastics in the Mediterranean basin may be overrepresented relative to the proportion of women in early career positions (assumed to be $30-50 \%$ [19]), and just as likely to be last authors in microplastics studies as men, perhaps suggesting women in this field are just as likely to be in senior project/academic positions as men? A more detailed survey of the number of post-graduate students, post-doctoral research fellows and junior academic/other researchers would, however, need to be conducted to confirm that conclusion.

\section{Microplastics in the Mediterranean Environment Microplastics in surface water}

There have been more than forty articles reporting the levels of MPs in surface water since 1980, although not all differentiate microplastic data from that of other debris, including, for instance, the most cited 'first report' on MPs in the Mediterranean Sea [110]. Consequently, articles that did not differentiate between macro-, meso- and microplastic particles/debris are not considered in the following discourse.

As noted by Cincinelli et al. [46], there is a lack of standardized sampling methods for the collection of MPs in surface waters. The variety of study designs, including the number of replicates, gear and net mesh sizes complicates the comparison of different studies. The most commonly reported method of MPs identification is visual inspection of collected material using a microscope, albeit it is becoming more common that putative plastics 
are confirmed using analytical techniques such as Fourier Transform Infrared Spectroscopy (FTIR). Further complicating comparisons between studies is (a) the tendency for authors to report their findings in different units, e.g., MPs $/ \mathrm{km}^{2}, \mathrm{~g} / \mathrm{km}^{2}, \mathrm{mg} / \mathrm{m}^{3}$ and $/$ or MPs $/ \mathrm{m}^{3}$, (b) that not all studies report the size range of the MPs collected or their shapes, or (c) polymer types or (d) whether observed MPs are primary plastics e.g. virgin plastic resin pellets / microbeads or secondary particles resulting from the natural weathering of microplastic debris. This lack of standardization with respect to data reporting also makes estimating the potential impact of MPs in surface waters difficult, as noted by Everaert et al. [66].

The Strait of Sicily effectively divides the Mediterranean into Eastern and Western basins, with the
Dardanelles Strait and the Bosporus in turn separating the Eastern basin from the Sea of Marmara and the Black Sea. In that context, there have been several studies in the north western part of the Western basin. For instance, Faure et al. [69] and Schmidt et al. [135] both reported MPs levels in surface water in the Gulf of Lion (Table 5; MPs $/ \mathrm{km}^{2}$. Note: studies reporting data in $\mathrm{g} / \mathrm{km}^{2}, \mathrm{mg} /$ $\mathrm{m}^{3}$ and/or MPs $/ \mathrm{m}^{3}$ are summarised in Supplementary Information Tables S2, S3, S4). Schmidt et al. [135] sampled areas close to wastewater treatment plants and river mouths several times for a period of 2 years and reported mean concentrations of $112,000 \mathrm{MPs} / \mathrm{km}^{2}$. Those concentrations were similar to the results obtained from the earlier trawling study in the same region (130,000 MPs/ $\mathrm{km}^{2}$ [69]). Similar levels were, however, reported by de

Table 5 Summary of microplastic concentrations in Mediterranean seawater (MPs/ $\mathrm{km}^{2}$; all surface water samples)

\begin{tabular}{|c|c|c|c|c|c|c|}
\hline \multirow[t]{2}{*}{ Country } & \multirow[t]{2}{*}{ Location } & \multirow[t]{2}{*}{ Maritime Area } & \multicolumn{3}{|c|}{ MP concentration } & \multirow[t]{2}{*}{ Reference } \\
\hline & & & Min & Max & Mean & \\
\hline & & & \multicolumn{3}{|l|}{$\mathrm{MPs} / \mathrm{km}^{2}$} & \\
\hline Bulgaria & Burgas Bay to Cape Kaliakra & Black Sea & 11,400 & 191,000 & $46,200 \pm 54,700$ & Berov \& Klayn [20] \\
\hline Croatia & Archipelago of the Zadar County & Northern Central Adriatic Sea & 17,875 & $1,549,549$ & $127,135 \pm 294,847$ & Palatinus et al. [115] \\
\hline France & Gulf of Lion & Western Mediterranean & 6000 & $1,000,000$ & 112,000 & Schmidt et al. [135] \\
\hline France & Gulf of Lion & North western Mediterranean & 20,000 & 420,000 & 130,000 & Faure et al. [69] \\
\hline France & Bay of Calvi, Corsica & North Western Mediterranean & 0 & 613,000 & 51,000 & Collignon et al. [52] \\
\hline Israel & Israeli south coast & Israeli Mediterranean & & 64,813 & $1,518,340$ & van der Hal et al. [150] \\
\hline Italy & Province of Ascoli Piceno & Central Adriatic Sea & 5 & 400 & & Capriotti et al. [36] \\
\hline Italy & & Ligurian and Tyrrhenian Sea & 1286 & $3,666,898$ & $233,927 \pm 810,357$ & Caldwell et al. [31] \\
\hline Italy & & Ligurian and Tyrrhenian Sea & 505 & 93,983 & 19,220 & Caldwell et al. [30] \\
\hline Italy & Tuscany & Ligurian Sea & 3158 & 347,040 & $69,161 \pm 83,244$ & Baini et al. [14] \\
\hline Italy & Pelagos Sanctuary Protected Area & Ligurian and Sardinian Sea & & $4,830,000$ & & Fossi et al. [72] \\
\hline Slovenia & Piran Bay to Koper Bay & North Adriatic Sea & & & $259,310 \pm 57,096$ & Viršek et al. [153] \\
\hline Slovenia & Trieste Bay & Northern Adriatic Sea & 12,000 & $2,660,000$ & 406,000 & Gajst et al. [77] \\
\hline Spain & Balearic Islands & Balearic sea & & & $410,000 \pm 30,000$ & Capo et al. [35] \\
\hline Spain & Barcelona & Balearic sea & 18,000 & 330,000 & 94,500 & Camins et al. [32] \\
\hline Spain & $\begin{array}{l}\text { North Catalan coast \& south- } \\
\text { eastern coast of Spain }\end{array}$ & Western Mediterranean & 9000 & 497,000 & $102,000 \pm 90,000$ & de Haan et al. [58] \\
\hline Spain & Menorca Channel & Balearic sea & & & $133,517-336,131$ & Ruiz-Orejón et al. [129] \\
\hline Spain & Balearic Islands & Balearic sea & & & 875,466 & Ruiz-Orejón et al. [128] \\
\hline Turkey & Mersin Bay & Levantine Sea & 198,198 & $1,427,027$ & 539,189 & Gündoğdu et al. [83] \\
\hline Turkey & Mersin Bay & Levantine Sea & 881,319 & $19,344,417$ & $7,699,716$ & Gündoğdu et al. [83] \\
\hline Turkey & Iskenderun and Mersin Bay & Levantine Sea & & & 376,000 & Gündoğd and Cevik [82] \\
\hline Turkey & Iskenderun Bay & Levantine Sea & 98,412 & $2,888,889$ & $1,067,120$ & Gündoğdu [82] \\
\hline Turkey & South-eastern coast of Turkey & North-eastern Mediterranean & 16,339 & 520,213 & 140,418 & Guven et al. [85] \\
\hline \multirow[t]{5}{*}{ Turkey } & Sinop Sarikum Coast & Southern Black Sea & & & 656,000 & Oztekin and Bat [114] \\
\hline & Multiple locations & $\begin{array}{l}\text { Adriatic and Western Mediter- } \\
\text { ranean }\end{array}$ & & $4,520,000$ & $400,000740,000$ & Suaria et al. [141] \\
\hline & & $\begin{array}{l}\text { Adriatic and Western Mediter- } \\
\text { ranean }\end{array}$ & & & $1304,81 \pm 609,426$ & Suaria et al. [141] \\
\hline & & Mediterranean-wide & 0 & 479,455 & 48,789 & Eriksen et al. [65] \\
\hline & & North-western Mediterranean & 0 & 892,000 & 116,000 & Collignon et al. [51] \\
\hline
\end{tabular}


Haan et al. [58] off the coast of south-eastern coast of Spain $\left(102,000 \mathrm{MPs} / \mathrm{km}^{2}\right)$. Most recently, Camins et al. [32] reported an average of $94,500 \mathrm{MPs} / \mathrm{km}^{2}$ in the Balearic Sea, which was an order of magnitude lower than the concentrations reported for the same region in 2018 (875,466 MPs $/ \mathrm{km}^{2}$ [128]).

The Adriatic Sea in the Eastern Basin is often considered as one of the most polluted regions of the Mediterranean [141], in part because of the extensive marine traffic in the region, but also because of the large riverine inputs from the River Po [152], which flows through various industrial regions and opens to a wide delta in the northern part of the Adriatic, and the numerous touristic centres around the coastline. There has been a wide range of MPs concentrations reported in the Adriatic Sea, from low numbers in the central Adriatic (up to $400 \mathrm{MPs} / \mathrm{km}^{2}$ [36]) to several hundred thousand MPs $/ \mathrm{km}^{2}[77,153]$ (Table 5). Trieste and the river Po are among the top ten sources of marine litter in the Adriatic [104]. Data from just offshore of the Veneto lagoon suggests that average MPs levels close to the lagoon are almost three times higher than off the Po estuary (1.208 $\mathrm{MPs} / \mathrm{m}^{2}$ cf. 0.472 and $0.315 \mathrm{MPs} / \mathrm{m}^{2}$ [152]), as well as having a significantly higher maximum value $\left(10.4 \mathrm{MPs} / \mathrm{m}^{2} \mathrm{cf}\right.$. 3.098 and 3.234 $\mathrm{MPs} / \mathrm{m}^{2}$ ). Further east, Gündoğdu et al. [83] reported that MPs in the Levantine Sea increased 10-fold after rain (average 535,189 MPs $/ \mathrm{m}^{2}$ cf. 7,669,716 $\mathrm{MPs} / \mathrm{m}^{2}$ ). The Levantine coast of Turkey is heavily polluted by numerous industries and the reported abundance of MPs on the water surface reflects that influence [82]. There have been fewer reports of MPs in surface waters of the Black Sea, but these are consistent with other eastern Mediterranean basin studies, i.e., averaging tens of thousands of $\mathrm{MPs} / \mathrm{km}^{2}$ [20] to hundreds of thousands of MPs $/ \mathrm{km}^{2}$ [114].

Most of the studies sampling of surface waters filter only the topmost layer of water, which can be sufficiently representative in no/low-wind conditions, but less so when winds induce mixing of the water and trawls are unable to collect all the MPs that are pushed beneath the surface of the water [95]. Studies that sample sub-surface waters for MPs are limited to Lefebvre et al. [100], Baini et al. [14], and Oztekin and Bat [114] who reported $0.23 \pm 0.20,0.16 \pm 0.47$, and $24.475 \pm 26.153 \mathrm{MPs} / \mathrm{m}^{3}$ in the Gulf of Lion, the Ligurian Sea, and the Southern Black Sea, respectively (Table S4). Such types of investigations are rare because of the expense of sampling; however, they are necessary to fully understand the spatial distribution of MPs in the water column and the potential exposure of organisms therein.

\section{Microplastics in marine sediments}

There have been more than twenty articles reporting the levels of MPs in marine sediments since the first report in 2013, although not all differentiate microplastic data from that of other debris, including the most cited 'first report' on MPs in the Mediterranean Sea sediments [149]. Consequently, articles that did not differentiates between microplastic and larger particles/debris are not considered in the following discourse.

As noted by [102]) there is a lack of standardized sampling methods for the collection of MPs in sediments, with a variety of sediment grabs or corers used to collect samples.

Extraction of the MP particles from the sediment is typically done using a density separation method, most commonly by adding a defined density liquid to the sediment and stirring the mixture up. This allows for the MPs less dense than the liquid phase to rise to the surface, or stay in suspension as the denser sand, grit and gravels in the sediment settle. Most of the papers reviewed hereafter added $\mathrm{NaCl}$ to the sample, mixed for $2 \mathrm{~min}$, and then allowed the mixture to settle for $4 \mathrm{~min}$ before collecting MPs. A large proportion of MP particles can be lost in this process, especially the smaller sized pieces that can get fixed on the equipment used, or MPs made from high density polymers, e.g., PVC. Repeating this process several times with increasingly dense solutions allows for higher yields and greater recovery of denser polymers. Extraction efficiencies vary depending on the technique used, and also the shape, size and polymer type of the model particles used for recovery experiments, but extraction efficiencies in the range $80-100 \%$ have been reported [102]. The vast majority authors report their findings in MPs/kg sediment (dry weight), albeit g/ $\mathrm{kg}$ (d.w.) and $\mathrm{g} / \mathrm{kg}$ and MPs $/ \mathrm{m}^{2}$ have also been reported (Table S5).

There have been several recent studies in the southern part of the Western Mediterranean basin. In that context, Missawi et al. [107] and Abidli et al. [2] reported almost identical average levels of MPs in sediments in Tunisia (315 and 316 MPs/kg d.w., respectively; Table 6), albeit the highest concentrations observed by Abidli et al. [2] were in the Bizerte Lagoon (461.25 \pm 29.74 $\mathrm{MPs} / \mathrm{kg}$ ), whereas the highest concentration observed by Missawi et al. [107] were offshore in the Gulf of Cabes $(606 \pm 37.5 \mathrm{MPs} / \mathrm{kg})$. Both these locations are reportedly heavily polluted by agricultural, aquaculture and industrial wastewaters. Dahl et al. [57], Krüger et al. [94], and Filgueiras et al. [70] reported up to 3819, up to 213, and up to $440 \mathrm{MPs} / \mathrm{kg}$, respectively, off the Spanish coast, and around the Balearic Islands (Table 6). North of Sicily, Renzi et al. [122] found $49.0 \pm 1.4,153.5 \pm 41.7$, and $106.0 \pm 104.7 \mathrm{MPs} / \mathrm{kg}$ in sediments associated with landslides, cliffs, and banks, respectively, around Salina Island in the Tyrrhenian Sea.

To date, the lowest levels reported in sediments in the eastern Mediterranean have been in the Aegean Sea 
Table 6 A summary of the number of MPs found in marine sediments around the Mediterranean basin (items per kg dry weight)

\begin{tabular}{|c|c|c|c|c|c|c|}
\hline \multirow[t]{2}{*}{ Country } & \multirow[t]{2}{*}{ Location } & \multirow[t]{2}{*}{ Maritime Area } & \multicolumn{3}{|c|}{ MPs concentration } & \multirow[t]{2}{*}{ Reference } \\
\hline & & & Min & Max & Mean & \\
\hline & & & \multicolumn{3}{|l|}{ MPs/kg (d.w.) } & \\
\hline Croatia & Telašćica Archipelago & Adriatic Sea & 32.3 & 377.8 & $177.6 \pm 112.7$ & Renzi \& Blašković [119] \\
\hline Croatia & Silba Archipelago & Adriatic Sea & 113.4 & 284.8 & $86.0 \pm 98.4$ & Renzi \& Blašković [1 19] \\
\hline Croatia & Archipelago of the Zadar County & Northern Central Adriatic Sea & 190 & 780 & $360 \pm 169.1$ & Palatinus et al. [115] \\
\hline Croatia & Natural Park of Telašćica Bay & Adriatic Sea & 32 & 378 & 178 & Blašković et al. [23] \\
\hline Greece & Samos Island & Aegean Sea & 1 & 37 & 12 & de Ruijter et al. [59] \\
\hline Italy & Salina Island & Tyrrhenian Sea & & & $49.0 \pm 1.4$ & Renzi et al. [122] \\
\hline Italy & Salina Island & Tyrrhenian Sea & & & $153.5 \pm 41.7$ & Renzi et al. [122] \\
\hline Italy & Salina Island & Tyrrhenian Sea & & & $106.0 \pm 104.7$ & Renzi et al. [122] \\
\hline Italy & South Tuscany & Tyrrhenian Sea & 42 & 1069 & 317 & Cannas et al. [33] \\
\hline Italy & Maremma Regional Park & Tyrrhenian Sea & 45 & 397 & & Guerranti et al. [81] \\
\hline Italy & Aeolian Archipelago & Southern Tyrrhenian Sea & $151.0 \pm 34.0$ & $678.7 \pm 345.8$ & 371 & Fastelli et al. [68] \\
\hline Lebanon & Levantine Basin & Eastern Mediterranean & & & $2433 \pm 2000$ & Kazour et al. [91] \\
\hline Slovenia & Gulf of Trieste & Adriatic Sea & & & 170.4 & Laglbauer et al. [97] \\
\hline Spain & Almería coast and Balearic islands & West Mediterranean & 0 & 3819 & & Dahl et al. [57] \\
\hline Spain & Tarragona Coast & West Mediterranean & & & 32.4 & Expósito et al. [67] \\
\hline Spain & & West Mediterranean & 0 & 213 & $32-69$ & Krüger et al. [94] \\
\hline Spain & Algeciras to Barcelona coast & West Mediterranean & $45.9 \pm 23.9$ & $280.3 \pm 164.9$ & $113.2 \pm 88.9$ & Filgueiras et al. [70] \\
\hline Spain & Mallorca \& Carbera Islands & Balearic Sea & $100 \pm 60$ & $900 \pm 100$ & 270 & Alomar et al. [5] \\
\hline Tunisia & Tunisian coast & Southern Mediterranean & $129 \pm 10$ & $606 \pm 37.5$ & 314.5 & Missawi et al. [107] \\
\hline \multirow[t]{3}{*}{ Tunisia } & Northern Tunisian coast & Southern Mediterranean & $141.20 \pm 25.98$ & $461.25 \pm 29.74$ & $316.03 \pm 123.74$ & Abidli et al. [2] \\
\hline & & Black Sea & 0 & 390 & 106 & Cincinelli et al. [47] \\
\hline & Caorle shore & Northern Adriatic Sea & 137 & 703 & 255 & Renzi et al. [120] \\
\hline
\end{tabular}

(up to $37 \mathrm{MPs} / \mathrm{kg}$ d.w [59])., whereas the highest concentrations have been found along the Lebanese coast $(2433 \pm 2000 \mathrm{MPs} / \mathrm{kg}$ d.w [91]), perhaps because of poor local waste management or because Lebanon is a potential landfall for plastics from other Eastern Mediterranean regions [62]. Microplastic concentrations in Adriatic Sea sediments have typically been reported in the $10 \mathrm{~s}-100 \mathrm{~s} \mathrm{MPs} / \mathrm{kg}$, e.g., $86.0 \pm 98.4$ [119] and $360 \pm 169.1$ ([115]; Table 6), albeit much higher levels (up to $2175 \mathrm{MPs} / \mathrm{kg}$ ) have been reported in the Venice lagoon [151]. Similar levels have been reported in the Black Sea (up to $390 \mathrm{MPs} / \mathrm{kg}$ [47]).

\section{Microplastics on beaches}

There have been more than thirty articles reporting the levels of MPs in/on Mediterranean beaches since the first report in 1979. These articles report the presence of industrial plastic beads or granules, plastic. Fragments, and plastic fibres, albeit some studies do not provide concentration data or differentiate MPs from other plastic debris. There is a lack of standardized sampling methods for the collection of MPs from beaches [21, 98] with a variety of processes used for sampling, extraction, and subsequent quantification. The major inconsistencies relate to sampling location (usually on the high tideline where debris accumulates, but often stochastic), sampling design (e.g. beach walks for specific linear distance cf. quadrats at specified locations/distances apart), sample collection (e.g. collect only visible MP pieces by subjective judgement or bulk sampling), the depth sampled when bulk sampling (e.g. top $1 \mathrm{~cm}, 5 \mathrm{~cm}$ or up to $530 \mathrm{~cm}$ ) and units of measurement (abundance in surface area, weight or volume). Most of the studies analysed herein used bulk sampling as their technique, albeit the limitations associated with sample extraction and determination methods are consistent with those discussed earlier for water and marine sediments. The vast majority authors report their findings in MPs/kg sand (dry weight), albeit MPs $/ \mathrm{m}^{2}, \mathrm{~g} / \mathrm{m}^{3}$, and MPs $/ \mathrm{m}^{3}$ and have also been reported (Tables S6, S7, S8, S9).

In the western Mediterranean basin, Godoy et al. [79] reported maximum concentrations of MPs in the range $45.0 \pm 24.7 \mathrm{MPs} / \mathrm{kg}$ on beaches in the province of Granada (Table 7). This is lower than the $148 \pm 23$ to $156 \pm 29 \mathrm{MPs} / \mathrm{kg}$ reported by Lots et al. [103] in the Balearic Sea. The beaches around the Gulf of Lion had mean values of $112 \mathrm{MPs} / \mathrm{kg}$ [54]. Similar MPs concentrations have been observed in beaches on the Ionian 
Table 7 A summary of the number of MP found on beaches around the Mediterranean basin (items per kg of dry weight)

\begin{tabular}{|c|c|c|c|c|c|c|}
\hline \multirow[t]{2}{*}{ Country } & \multirow[t]{2}{*}{ Location } & \multirow[t]{2}{*}{ Maritime Area } & \multicolumn{3}{|c|}{ MPs concentration } & \multirow[t]{2}{*}{ Reference } \\
\hline & & & Min & Max & Mean & \\
\hline & & & \multicolumn{3}{|c|}{ (MPs/kg of dry weight) } & \\
\hline Algeria & Gulf of Annaba & Western Mediterranean & $182.66 \pm 27.32$ & $649.33 \pm 184.02$ & & Tata et al. [142] \\
\hline Bosnia & & Central Adriatic Sea & & & $76 \pm 13$ & Lots et al. [103] \\
\hline France & Gulf of Lion & Western Mediterranean & 12 & 798 & 112 & Constant et al. [54] \\
\hline France & Cassis & Western Mediterranean & & & $124 \pm 36$ & Lots et al. [103] \\
\hline Greece & Samos Island & Aegean Sea & $1.1 \pm 0.9$ & $37.2 \pm 6.9$ & $11.5 \pm 10.5$ & De Ruijter et al. [59] \\
\hline Greece & Northern Crete & Aegean Sea & $5 \pm 5$ & $85 \pm 141$ & & Piperagkas et al. [118] \\
\hline Greece & Salamina Island & Aegean Sea & & & & Tziourrou et al. [146] \\
\hline Greece & Pilion & Aegean Sea & & & $232 \pm 93$ & Lots et al. [103] \\
\hline Israel & Tel Aviv & Israeli Mediterranean & & & $168 \pm 16$ & Lots et al. [103] \\
\hline Italy & Maremma Regional Park & Tyrrhenian Sea & 134 & 1069 & & Guerranti et al. [81] \\
\hline Italy & San Mauro & Northern Adriatic Sea & & & $84 \pm 12$ & Lots et al. [103] \\
\hline Italy & Lido di Dante & Northern Adriatic Sea & & & $1512 \pm 187$ & Lots et al. [103] \\
\hline Italy & Sicily & Ionian Sea & & & $160 \pm 31$ & Lots et al. [103] \\
\hline Malta & & Central Mediterranean & 1.07 & 10.95 & & Axiak et al. [13] \\
\hline Malta & & Central Mediterranean & & & & Turner and Luke Holmes [145 \\
\hline Slovenia & & Adriatic Sea & 0 & $3.1 \pm 2.6$ & & Korez et al. [93] \\
\hline Slovenia & Gulf of Trieste & Adriatic Sea & & 177.8 & & {$[97]$} \\
\hline Spain & Tarragona Coast & Western Mediterranean & & & 10.7 & Expósito et al. [67] \\
\hline Spain & La Herradura, Granada & Alboran Sea & & & $45.0 \pm 24.7^{*}$ & Godoy et al. [79] \\
\hline Spain & Motril, Granada & Alboran Sea & & & $31.5 \pm 21.5^{*}$ & Godoy et al. [79] \\
\hline Spain & La Rábita, Granada & Alboran Sea & & & $22.0 \pm 23.28^{*}$ & Godoy et al. [79] \\
\hline Spain & Barcelona & Balearic Sea & & & $148 \pm 23$ & Lots et al. [103] \\
\hline Spain & Denia & Balearic Sea & & & $156 \pm 29$ & Lots et al. [103] \\
\hline Turkey & & Sea of Marmara & & & $8.38 \pm 7.77$ & Artüz et al. [8] \\
\hline Turkey & Istanbul & Black Sea & & & 20.7 & Şener et al. [136] \\
\hline Turkey & Datça Peninsula & Aegean Sea & 593 & 2073 & 1154 & Yabanli et al. [156] \\
\hline Turkey & Dikili & Aegean Sea & & & $248 \pm 29$ & Lots et al. [103] \\
\hline
\end{tabular}

Sea $(160 \pm 31 \mathrm{MPs} / \mathrm{kg}$ [103]). In comparison, the Tyrrhenian Sea seems may have accumulated more MP debris. For instance, Guerranti et al. [81] reported up to $1069 \mathrm{MPs} / \mathrm{kg}$, albeit from samples near a river mouth (Table 7). River mouths are an important source of MP pollution into the sea, and in that context, SimonSánchez et al. [139] reported $422 \pm 119 \mathrm{MPs} / \mathrm{kg}$ in the Ebro River delta, while Blašković et al. [24] found a maximum of $191 \mathrm{MPs} / \mathrm{kg}$ in the Cecina River estuary (Ligurian Sea).

In the eastern basin, there have been multiple reports from the Adriatic Sea with concentrations ranging from the very low $(\max 3.1 \pm 2.6$ items $/ \mathrm{kg}$ [93]; Table 7$)$ to intermediate $(76 \pm 13$ items $/ \mathrm{kg}$ [103]) to high levels $(1512 \pm 187$ items $/ \mathrm{kg}$ [103]). The latter sampling location was between the mouths of two rivers, which again highlights the importance of riverine inputs. Beach sediments on both the Greek and Turkish coasts of the
Aegean Sea had $232 \pm 93$ and $248 \pm 29 \mathrm{MPs} / \mathrm{kg}$, respectively [103]. An exceptionally high mean abundance of $1154 \mathrm{MPs} / \mathrm{kg}$ has been observed on a tourist beach after the peak tourist season in the Aegean Sea in Turkey [156]. Much lower levels were reported from a tourist beach on Samos Island in the Aegean Sea also sampled after peak tourist season (mean abundance $11.5 \pm 10.5$ $\mathrm{MPs} / \mathrm{kg}$ [59]). When the numbers of MPs are reported on an aereal basis $\left(27 \mathrm{MPs} / \mathrm{m}^{2}\right)$, De Ruijter et al. suggest that beach would be classified as, "extremely dirty".

\section{Microplastics in field collected biota}

There have been more than forty articles reporting the levels of MPs in Mediterranean biota since 1979. These articles mostly report the presence of plastic and plastic fibres, albeit some studies do not provide concentration data or differentiate MPs from other plastic debris. There is a lack of standardized sampling methods for the 
collection of MPs from organisms Lakshmi Kavya et al. [98], with how samples are collected is a major variable, i.e., market basket surveys $\mathrm{cf}$. the wide variety of field sampling protocols used. However, a major inconsistency relates to methods used to separate MPs from extraneous biological material, including whether acid or alkali or enzymes are used to decompose tissues, and the temperature at which the decomposition is undertaken. Most of the studies analysed herein report numerical abundance per organism, albeit the limitations associated with determination methods are consistent with those discussed earlier for water and marine sediments.

Anchovy (Engraulis encrasicolus), sardines (Sardina pilchardus) and the bogue (Boops boops) are amongst the most commonly studied fish, and, in that context the number of MPs reported in fish in the western Mediterranean basin are generally very low, typically only a few MPs per organism (Table 8). The picture is, however, mixed. For instance, $12 \%$ of sardines and $11 \%$ of anchovy in French coastal waters were reportedly contaminated with $0.20 \pm 0.69$ and $0.11 \pm 0.31 \mathrm{MPs} / \mathrm{org}$, respectively [100]. A higher percentage of anchovy and sardines contaminated with higher levels of MPs was observed in the Alboran Sea off the Iberian coast (anchovy, 87\%, $1.92 \pm 0.95 \mathrm{MPs} /$ org; sardines, $87 \%, 1.77 \pm 1.42 \mathrm{MPs} /$ org, respectively [71]). Forty-seven percent of bogue in French coastal waters were contaminated by an average $1.77 \pm 0.22 \mathrm{MPs} /$ org [144]), with similar (47\%; $1.85 \pm 0.15$ MPs/org) as well as higher values ( $81 \% ; 3.97 \pm 0.23$ MPs/org) reported in the Tyrrhenian Sea [144], and the Balearic Sea (46\%; $1.96 \pm 0.20 \mathrm{MPs} /$ org [144]) and 58\%, $3.75 \pm 0.25 \mathrm{MPs} /$ org [111]). The highest levels of contamination were seen in the blackmouth catshark (Galeus melastomus; 78\%, 4.47 $\pm 1.10 \mathrm{MPs} /$ org [148]) and the silver scabbardfish (Lepidopus caudatus; 78\%, 4.8 MPs/org, [26]) from the Tyrrhenian Sea.

Fish in the eastern Mediterranean basin are also consistently contaminated with a few MPs per organism (Table 9), albeit the highest levels reported in fish are in organisms collected in the Adriatic Sea, e.g., in the golden grey mullet (Chelon auratus, 95\%; 9.9 $\pm 8.1 \mathrm{MPs}$ / org) and gilt head bream (Sparus aurata, 100\%, $7.3 \pm 6.6$ MPs/org [6]).

Filter feeding invertebrates in the Mediterranean have also been shown to contain MPs (Tables S10, S11). The most contaminated bivalves were oysters from the Levantine Basin (Scutiger spinosus, 86\%, 7.2 $\pm 1.4 \mathrm{MPs}$ / org [91]). Mussels (Mytilus spp.) have tended to be less contaminated (e.g., 46\%; 1.9 $\pm 0.2 \mathrm{MPs} /$ org [61]). Sixtysix percent of shrimp (Aristeus antennatus) in Sardinia had 1.66 $\pm 0.1 \mathrm{MPs} /$ org [39]. These were less contaminated than lobster (Nephrops norvegicus, 83\%, $5.5 \pm 0.8$ MPs/org from the same waters.
Studies that target microplastic exposure in marine mammals, turtles and seabirds are limited due to the large size of the animals, their protected status and the challenges of obtaining reliable samples in good condition at the time of post-mortem analysis [17]. But, in that context, there have been two studies of MPs in dolphins in the Mediterranean (Table S12). For instance, Novillo et al. [113] reported $91 \%$ of striped dolphin (Stenella coeruleoalba) from the Balearic Sea had MPs in their digestive system (14.9 $\pm 22.3 \mathrm{MPs} / \mathrm{org})$. Similarly, $100 \%$ of the short-beaked common dolphin (Delphinus delphis) found on the Galician Coast and examined by Hernandez-Gonzalez et al. [87] were contaminated by MPs (12 $\pm 8 \mathrm{MPs} / \mathrm{org})$. There has been one report of MPs in Mediterranean Sea turtles, with Di Renzo et al. [60] reporting that $66 \%$ of Adriatic Sea loggerhead turtles (Caretta caretta) they investigated were contaminated by an average of $4.75 \mathrm{MPs} / \mathrm{org}$. There has also only been one study of MPs in Mediterranean seabirds, with the highest levels of MPs observed in Northern Gannet (Morus bassanus, $49.3 \pm 77.7 \mathrm{MPs} /$ org [49]).

\section{Microplastics characteristics}

Presentation of information on the type and colour of MPs is common in the reviewed papers. Some studies were content to present information on the size and shape of the MPs, and to classify them as fibres, films, foams, and fragments, while many also described the surface characteristics such as colour.

\section{Colour}

In 94 of the 166 studies reviewed, the colours of the MPs observed were reported, including whether they were colourless, white, yellow, green, brown, red, blue or black (Kutralam-Muniasamy et al. [96] suggest that colour affects the sorting of MPs under stereomicroscopes, potentially affecting the number and type of particles identified. In all the matrices examined, black/blue coloured MPs were dominant.

\section{Shape}

The shape of MPs can indicate their potential origins. For instance, plastic resin pellets represent fugitive losses during the transport and use of these primary MPs, whereas secondary MPs such as fibres may be derived from synthetic textiles and fishing nets. Microplastics shapes were described in almost all the studies reviewed. Fibres were the most frequent shape reported across all sample types. That this was the most dominant shape reported was perhaps to be expected as it has been found that a single garment can release more than 1900 fibres in one washing machine cycle [29]. 
Table 8 A summary of the number of MP items found in fish around the western Mediterranean basin

\begin{tabular}{|c|c|c|c|c|c|c|}
\hline Country & Location & Area & Name & Mean & Freq *a & Reference \\
\hline & & & & MPs/animal & (\%) & \\
\hline France & French coastal waters & $\begin{array}{l}\text { Northwestern Mediter- } \\
\text { ranean }\end{array}$ & Boops boops & $1.77 \pm 0.22$ & 47 & Tsangaris et al. [144] \\
\hline France & Gulf of Lion & $\begin{array}{l}\text { Northwestern Mediter- } \\
\text { ranean }\end{array}$ & Sardina pilchardus & $0.20 \pm 0.69^{a}$ & 12 & Lefebvre et al. [100] \\
\hline France & Gulf of Lion & $\begin{array}{l}\text { Northwestern Mediter- } \\
\text { ranean }\end{array}$ & Engraulis encrasicolus & $0.11 \pm 0.31^{\mathrm{a}}$ & 11 & Lefebvre et al. [100] \\
\hline France & Gulf of Lion & $\begin{array}{l}\text { Northwestern Mediter- } \\
\text { ranean }\end{array}$ & Engraulis encrasicolus & 1.13 & 80 & Collard et al. [50] \\
\hline Italy & Anzio & Tyrrhenian sea & $\begin{array}{l}\text { Scomber colias, Merluccius } \\
\text { merluccius, Trigla lyra }\end{array}$ & 2.73 & 66 & Bianchi et al. [22] \\
\hline Italy & Sicily & Southern Tyrrhenian Sea & $\begin{array}{l}\text { Mullus barbatus, Trigla } \\
\text { lyra, Galeus melastomus, } \\
\text { Scyliorhinus canicular, Raja } \\
\text { miraletus }\end{array}$ & 1.72 & 17 & Capillo et al. [34] \\
\hline Italy & Sicily & Southern Tyrrhenian Sea & Sardina pilchardus & $0.53^{\mathrm{a}}$ & & Savoca et al. [132] \\
\hline Italy & Sicily & Southern Tyrrhenian Sea & Engraulis encrasicolus & $0.26^{\mathrm{a}}$ & & Savoca et al. [132] \\
\hline Italy & $\begin{array}{l}\text { Latium, Sardinia and } \\
\text { Liguria }\end{array}$ & $\begin{array}{l}\text { Tyrrhenian and Ligurian } \\
\text { Sea }\end{array}$ & Boops boops & $1.8 \pm 0.2$ & 56 & Sbrana et al. [133] \\
\hline Italy & Sicily & Southern Tyrrhenian Sea & Coryphaena hippurus & 3.9 & 65 & Schirinzi et al. [134] \\
\hline Italy & Liguria & $\begin{array}{l}\text { Northwestern Mediter- } \\
\text { ranean }\end{array}$ & Boops boops & $1.85 \pm 0.15$ & 47 & Tsangaris et al. [144] \\
\hline Italy & Lazio & Tyrrhenian Sea & Boops boops & $3.97 \pm 0.23$ & 81 & Tsangaris et al. [144] \\
\hline Italy & South Sardinia & Tyrrhenian Sea & Boops boops & $1.46 \pm 0.24$ & 13 & Tsangaris et al. [144] \\
\hline Italy & Sicily & Tyrrhenian Sea & Lepidopus caudatus & 4.8 & 78 & Bottari et al. [26] \\
\hline Italy & Sicily & Tyrrhenian Sea & Zeusfaber & $2.1^{\mathrm{a}}$ & 51 & Bottari et al. [26] \\
\hline Italy & $\begin{array}{l}\text { Leghorn, Taranto and } \\
\text { Ortona }\end{array}$ & $\begin{array}{l}\text { North Tyrrhenian Sea, Adri- } \\
\text { atic Sea and lonian Sea }\end{array}$ & Mullus barbatus & 1.08 & 20 & Giani et al. [78] \\
\hline Italy & $\begin{array}{l}\text { Leghorn, Taranto and } \\
\text { Ortona }\end{array}$ & $\begin{array}{l}\text { North Tyrrhenian Sea, Adri- } \\
\text { atic Sea and lonian Sea }\end{array}$ & Merluccius merluccius & 1.38 & 27 & Giani et al. [78] \\
\hline Italy & Sicily & Tyrrhenian Sea & Merluccius merluccius & 1 & 46 & Mancuso and Bottari [105] \\
\hline Italy & $\begin{array}{l}\text { Rasocolmo Cape and } \\
\text { Termini Imerese }\end{array}$ & Tyrrhenian Sea & Pagellus spp. & & 9 & Savoca et al. [131] \\
\hline Country & Location & Area & Name & $\begin{array}{l}\text { Mean } \\
\text { MPs/animal }\end{array}$ & $\begin{array}{l}\text { Frequency } \\
\text { (\%) }\end{array}$ & Reference \\
\hline Italy & & Tyrrhenian Sea & Galeus melastomus & $4.47 \pm 1.10$ & 78 & Valente et al. [148] \\
\hline Italy & & Tyrrhenian Sea & Scyliorhinus canicula & $2.50 \pm 0.52$ & 67 & Valente et al. [148] \\
\hline Italy & & Tyrrhenian Sea & Etmopterus spinax & $1.18 \pm 0.26$ & 62 & Valente et al. [148] \\
\hline Italy & Giglio Island & Tyrrhenian Sea & $\begin{array}{l}\text { Scorpaena sp., Uranosco- } \\
\text { pus scaber, Phycis phycis, } \\
\text { Spondyliosoma cantharus }\end{array}$ & $2.47 \pm 2.0$ & 77 & Avio et al. [1 1] \\
\hline Italy & Giglio Island & Tyrrhenian Sea & 41 fish types & $4.0 \pm 1.83$ & 95 & Avio et al. [1 1] \\
\hline Italy & Strait of Messina & Central Mediterranean Sea & Trachinotus ovatus & & 24 & Battaglia et al. [16] \\
\hline Italy & Strait of Sicily & Central Mediterranean Sea & Myctophidae & 1 & 3 & Romeo et al. [126] \\
\hline Italy & Aeolian Islands & Tyrrhenian Sea & $\begin{array}{l}\text { Xiphias gladius, Thunnus } \\
\text { thynnus and Thunnus } \\
\text { alalunga }\end{array}$ & 1.32 & 18 & Romeo et al. [125] \\
\hline Spain & Iberian coast & Alboran Sea & Engraulis encrasicolus & $1.92 \pm 0.95$ & 87 & Filgueiras et al. [71] \\
\hline Spain & Iberian coast & Alboran Sea & Sardina pilchardus & $1.77 \pm 1.42$ & 87 & Filgueiras et al. [71] \\
\hline Spain & Iberian coast & Alboran Sea & Callionymus lyra & $2.53 \pm 1.88$ & 79 & Filgueiras et al. [71] \\
\hline Spain & Iberian coast & Alboran Sea & Mullus surmuletus & $1.56 \pm 0.53$ & 60 & Filgueiras et al. [71] \\
\hline Spain & $\begin{array}{l}\text { Central region of the Span- } \\
\text { ish coast }\end{array}$ & Western Mediterranean & Boops boops & $1.74 \pm 0.14$ & 53 & Tsangaris et al. [144] \\
\hline
\end{tabular}


Table 8 (continued)

\begin{tabular}{|c|c|c|c|c|c|c|}
\hline Country & Location & Area & Name & Mean & Freq *a & Reference \\
\hline Spain & $\begin{array}{l}\text { Northern coast of Cata- } \\
\text { lonia }\end{array}$ & Balearic sea & Boops boops & $1.96 \pm 0.20$ & 46 & Tsangaris et al. [144] \\
\hline Spain & Alicante & Balearic Sea & Sardina pilchardus & $1-2$ & 58 & Pennino et al. [117] \\
\hline Spain & Mallorca Island & Balearic Sea & Galeus melastomus & $0.34 \pm 0.07^{\mathrm{a}}$ & 16 & Alomar \& Deudero [3] \\
\hline Spain & Catalan coast & Balearic Sea & Boops boops & $1.42-2.59$ & 46 & Garcia-Garin et al. [76] \\
\hline Spain & Iberian Peninsula coast & Balearic and Alboran sea & Trachurus mediterraneus & $1.13 \pm 1.99^{\mathrm{a}}$ & 43 & Rios-Fuster et al. [123] \\
\hline Spain & Balearic Islands & Balearic Sea & Engraulis encrasicolus & $0.03 \pm 0.16^{\mathrm{a}}$ & 3 & Rios-Fuster et al. [123] \\
\hline Spain & Spanish coast & Alboran and Balearic Sea & Sardina pilchardus & $0.21 \pm 0.23^{\mathrm{a}}$ & 15 & Compa et al. [53] \\
\hline Spain & Spanish coast & Alboran and Balearic Sea & Engraulis encrasicolus & $0.18 \pm 0.20^{\mathrm{a}}$ & 14 & Compa et al. [53] \\
\hline Spain & Mallorca Island & Balearic Sea & Mullus surmuletus & $0.42 \pm 0.04^{\mathrm{a}}$ & 27 & Alomar et al. [4] \\
\hline Spain & $\begin{array}{l}\text { Barcelona, Cartagena, } \\
\text { Málaga, Ciutadella and } \\
\text { Mahon }\end{array}$ & Alboran and Balearic Sea & Mullus barbatus & $1.9 \pm 1.29$ & 19 & Bellas et al. [18] \\
\hline Spain & Balearic Islands & Balearic Sea & Boops boops & $3.75 \pm 0.25$ & 58 & Nadal et al. [111] \\
\hline
\end{tabular}

${ }^{a}$, calculated from Author figures/data; Frequency, \% of species that ingested MPs out of all sampled species

Table 9 A summary of the number of MP items found in fish around the eastern Mediterranean basin

\begin{tabular}{|c|c|c|c|c|c|c|}
\hline \multirow[t]{2}{*}{ Country } & \multirow[t]{2}{*}{ Location } & \multirow[t]{2}{*}{ Area } & \multirow[t]{2}{*}{ Name } & Mean & Frequency (\%) & \multirow[t]{2}{*}{ Reference } \\
\hline & & & & \multicolumn{2}{|c|}{ MPs/animal } & \\
\hline Croatia & & Northern and Middle Adriatic Sea & Mullus surmuletus & $2.7 \pm 1.8$ & 70 & Anastasopoulou et al. [6] \\
\hline Croatia & & Northern and Middle Adriatic Sea & Pagellus erythrinus & $2.1 \pm 1.6$ & 50 & Anastasopoulou et al. [6] \\
\hline Croatia & & Northern and Middle Adriatic Sea & Sardina pilchardus & $2.5 \pm 1.1$ & 37 & Anastasopoulou et al. [6] \\
\hline Greece & Kefallonia & Southern Ionian Sea & Boops boops & $1.13 \pm 0.07$ & 21 & Tsangaris et al. [144] \\
\hline Greece & Saronikos Gulf & Aegean Sea & Boops boops & $1.45 \pm 0.25$ & 30 & Tsangaris et al. [144] \\
\hline Greece & Corfu island & North eastern Ionian Sea & Mullus barbatus & $1.5 \pm 0.8$ & 32 & Anastasopoulou et al. [6] \\
\hline Greece & Corfu island & North eastern Ionian Sea & Pagellus erythrinus & $1.9 \pm 0.6$ & 42 & Anastasopoulou et al. [6] \\
\hline Greece & Corfu island & North eastern Ionian Sea & Sardina pilchardus & $1.8 \pm 0.9$ & 47 & Anastasopoulou et al. [6] \\
\hline Greece & Corfu Island & Northern Ionian Sea & Sardina pilchardus & $1.8 \pm 0.2$ & 47 & Digka et al. [61] \\
\hline Greece & Corfu Island & Northern Ionian Sea & Pagellus erythrinus & $1.9 \pm 0.2$ & 42 & Digka et al. [61] \\
\hline Greece & Corfu Island & Northern Ionian Sea & Mullus barbatus & $1.5 \pm 0.3$ & 32 & Digka et al. [61] \\
\hline Italy & Venice & Northern Adriatic Sea & 13 fish species & $1.46 \pm 0.52$ & 16 & Avio et al. [12] \\
\hline Italy & Ancona and Pescara & Central Adriatic Sea & 13 fish species & $1.32 \pm 0.48$ & 35 & Avio et al. [12] \\
\hline Italy & Bari and Lecce & Southern Adriatic Sea & 13 fish species & $1.14 \pm 0.36$ & 31 & Avio et al. [12] \\
\hline Italy & & Central Adriatic Sea & Sardina pilchardus & 4.63 & 96 & Renzi et al. [121] \\
\hline Italy & & Central Adriatic Sea & Engraulis encrasicolus & 1.25 & 91 & Renzi et al. [121] \\
\hline Lebanon & Levantine Basin & Eastern Mediterranean & Engraulis encrasicolus & $2.5 \pm 0.3$ & 83 & Kazour et al. [91] \\
\hline Slovenia & & Northern Adriatic Sea & Chelon auratus & $9.9 \pm 8.1$ & 95 & Anastasopoulou et al. [6] \\
\hline Slovenia & & Northern Adriatic Sea & Sparus aurata & $7.3 \pm 6.6$ & 100 & Anastasopoulou et al. [6] \\
\hline Slovenia & & Northern Adriatic Sea & Solea solea & $2.9 \pm 2.9$ & 65 & Anastasopoulou et al. [6] \\
\hline \multirow[t]{8}{*}{ Turkey } & Southeastern coast & North eastern Mediterranean & 28 types of fish & 2.36 & 58 & Güven et al. [85] \\
\hline & & $\begin{array}{l}\text { Northern and Central Adriatic } \\
\text { Sea }\end{array}$ & Solea solea & $1.73 \pm 0.05$ & 95 & Pellini et al. [116] \\
\hline & & $\begin{array}{l}\text { Northern and Central Adriatic } \\
\text { Sea }\end{array}$ & Solea solea & $1.64 \pm 0.1$ & & Pellini et al. [116] \\
\hline & & Central and North Adriatic Sea & Sardina pilchardus & $1.78 \pm 0.7$ & 19 & Avio et al. [10] \\
\hline & & Central and North Adriatic Sea & Squalus acanthias & $1.25 \pm 0.5$ & 44 & Avio et al. [10] \\
\hline & & Central and North Adriatic Sea & Merluccius merlucius & $1.33 \pm 0.57$ & 100 & Avio et al. [10] \\
\hline & & Central and North Adriatic Sea & Mullus barbatus & $1.57 \pm 0.78$ & 64 & Avio et al. [10] \\
\hline & & Central and North Adriatic Sea & Chelidonichthys lucernus & $1 \pm 0$ & 67 & Avio et al. [10] \\
\hline
\end{tabular}




\section{Size}

Particle size affects MP transport and fate, and the way they interact with biota. The size distribution of microplastics was described in 96 studies. The size distribution of MPs varied widely across the studies: MP sizes were typically in the range: $300-5000 \mu \mathrm{m}$ in surface water, $1-2 \mathrm{~mm}$ on beaches and in sediment, and $>0.50-1.5 \mathrm{~mm}$ in biota. There is no available data on small sized microplastics $(<50 \mu \mathrm{m})$ in the environment and biota.

\section{Polymer characterisation}

Most studies identified polymer type, with the three polymers most frequently reported being polyethylene (PE), polypropylene (PS) and polystyrene (PS). This is consistent with PP and PE being the polymers most commonly used in single use, disposable plastic products (SUPs), such as plastic packaging and disposable water bottles [45], and PS being widely used for take-away food containers and thermal insulation. In biota, PE was the most commonly reported polymer, with smaller amounts of PS and PP; on beaches, polyester was the most frequently reported polymer; nylon fibres were most commonly reported in water samples.

\section{Chemical contamination}

Microplastics can sorb and accumulate pollutants from surrounding water and doing so as informal passive samplers for trace metals and trace organic chemicals. In part, this is due to their small size and large surface to volume ratio, but also the materials from which they are made. For instance, PE typically sorbs more organic chemicals than other kinds of microplastics, and aged microplastics to sorb more pollutants than virgin materials [84]. The polarity of dissolved chemicals also plays a role in sorption, with non-polar chemicals more likely to sorb to non-polar MPs, and, similarly, polar chemicals more likely to sorb to MPs with polar functional groups, e.g., the nonpolar perfluorooctanesulfonamide partitions more readily onto nonpolar PE, whereas some polar antibiotics sorb readily onto the relatively polar plastic, polyacrylamide (PA). Sorbed chemical concentrations on MPs may depend on the proximity to pollution sources, i.e., sampling near the pollution sources can produce higher chemical burdens than those far from the pollution sources. Microplastic materials may also contain a range of chemical additives used during the production process, and these, along with sorbed chemicals, may also become available to organisms on ingestion. However, there are few studies reporting chemical contamination of MPs in the Mediterranean. Capriotti et al. [36] screened MPs collected in the Adriatic Sea for PCBs, PAHs, DDTs and a small number of organophosphate pesticides, noting a clear difference between inshore and offshore samples. For instance, inshore MPs were contaminated by $65.67 \mathrm{ng} / \mathrm{g}$-plastic $\Sigma \mathrm{PCB}$ compared to 37.78 at offshore sites. A significant amount of information on the level of chemical contamination of plastic resin pellets is available on the International Pellet Watch website (http://pelletwatch.org/), albeit the Pellet Watch site does not report pellet concentration. In our database, Karapanagioti et al. [90] was the only detailed report of sorbed chemicals on pellets collected from beaches, reporting median PCB concentrations (PCB66-206) in the range $66-270,000 \mathrm{pg} / \mathrm{g}$ plastic resin pellet, with pellets collected from beaches near known pollution sources being 1-2 orders of magnitude more contaminated than pellets from remote beaches with no known local pollution source.

\section{Limitations}

Similar to other studies that utilise a bibliometric approach [9], this study has several limitations. For instance, the bibliometric analysis in this study was limited to documents written in English detectable by the adopted search strategy in 2020. Grey literature, e.g., reports and internet sources, were not included in the bibliometric analysis. The search strategy retrieved publications from both the Scopus and the WoS databases, and from other sources through secondary searching of publication bibliographies, but despite this, relevant publications may have been missed. Third, while every attempt was made to standardise terms and authors' names by compiling an alias directory in CiteSpace, certain minor cases may have been overlooked; however, it is unlikely that this will have a major effect on the overall findings.

Some environmental compartments were deliberately excluded from the bibliometric and systematic analysis, e.g., harbours, small almost entirely enclosed lagoon systems and riverine estuaries. These locations are known to be more heavily contaminated than other marine environments. For instance, Abidli et al. [2] found relatively high levels of MPs in surface sediments in harbors on the Northern Tunisian coast (316 items/kg dry weight), and Abidli et al. [1] 3000-18,000 items /kg dry sediments collected from the almost entirely enclosed Lagoon of Bizerte. Lagoon waters are also highly contaminated. For instance, Çullu et al. [56] observed MP abundance or the order 33000 particles/L in surface waters of the Küçükçekmece Lagoon, Turkey. Wastewater treatment plant inputs were also not included in this review. In general, these facilities are considered to be important local sources of MPs [101], albeit that may not always be realised in environmental surveys. In that context, Lots et al. [103] sampled three sites associated with human sewage inputs in the Mallorca islands, and two locations on the 
Carbera islands that are sewage free and noted a higher abundance of debris in the Carbera island sites, rather than the more heavily impacted site in the Mallorca island. Even though such studies are extremely valuable in pinpointing major sinks and accumulation sites, they were excluded from further analyses because they do not reflect the average abundance of MPs in the rest of the Mediterranean. They do, however, highlight the need for considering oceanographic factors in the distribution of marine debris, such as winds, currents and halo- and thermohalines.

This review did not include laboratory ecotoxicology experiments or ecological risk assessments unless papers specifically included field measurements of MPs. In that context, there is an increasing number of studies that show that once microplastics are ingested by organisms that live in the Mediterranean Sea they have the potential to cause physical and toxicological harm. For instance, Bråte et al. [28] and Gonçalves et al. [80] both showed that MPs may be retained by filter feeders such as mussels. Bråte et al. [28] suggest that with PE MPs this can lead to injury of the gills and digestive system, whereas Gonçalves et al. [80] found that PS MPs were rapidly excreted by the mussels with no histopathological effects. Polystyrene microbeads did, however, affect metamorphosis of the ascidian Ciona robusta [106]. One group of organisms perhaps at particular risk from nanoand MPs are corals. Savinelli et al. [130] have shown that MPs impair the feeding efficiency of Astroides calycularis polyps when they co-occur with food items. Such studies can be integrated for probabilistic risk assessments, e.g., Everaert et al. [66] quantified the risk of MP for each year between 1950 and 2100 and found strong indications that $67 \%$ organisms in parts of the Mediterranean Sea will be at risk from MPs by 2100 .

More generally, the major limitation when comparing contamination in different locations is the presentation of MP abundance in different units. A simple solution for this problem is recording multiple parameters for the MPs while undertaking the research project, e.g., number, size, volume, and weight and presenting the data in as possible different units to make them comparable. For instance, reporting floating MPs as MPs per unit volume as well as per unit area. For marine sediments and beach materials, presenting abundance as a number of items per weight or volume is the least representative method, as the sizes of the MPs are widely different. A better representation may be the total volume of MPs per volume of substrate, albeit determining the volume of MPs would be extremely time-consuming and demanding unless and until automated instrumental methods are more widely available. And in that context, collecting a sample from the surface or the top $5 \mathrm{~cm}$ only has been reported to be an underestimation of the total plastic debris that is accumulated on beaches. Carson et al. [38] found that only $50 \%$ of the sampled plastic was in the top $5 \mathrm{~cm}$, while up to $95 \%$ was in the top $15 \mathrm{~cm}$. Temporal sampling through different seasons and conditions are also crucial in obtaining accurate results for the presence of MP yearround to account for overcompensation, such as from touristic seasons.

\section{Conclusions}

Interest in MP abundance in the Mediterranean Sea has been particularly high in the past 5 years (2016-2020). The abundance of MPs on beaches, and in surface waters, sediments and biota are among the highest levels reported worldwide. Secondary microplastics, such fibres and fragments, of a wide range of sizes and chemical composition were dominant in scientific reports, albeit citizen science collection of plastic resin pellets for International Pellet Watch suggests such primary MPs are also widespread, even if their numerical abundance from such collections is unclear. Hereafter, we present some recommendations for further research, many of which are the same as put forward by Galgani et al. [75] almost a decade ago. Based on the evidence presented in this paper, areas that merit immediate attention are summarized as follows:

(1) Understanding the abundance of MPs is the first step towards understanding the extent of microplastics contamination in the region. It is important to expand the scientific efforts in countries bordering the southern Mediterranean Sea, the Levantine Sea, and the Black Sea where there is insufficient knowledge on the abundance and potential impacts of MPs in the environment.

(2) Long-term extensive monitoring programmes should be carried out to better quantify the spatial distribution of MPs in a wider range of Mediterranean sub-regions. In that context, further comprehensive understanding on the contribution of point sources such as rivers, WWTP discharges, is needed to improve measures to stop plastic debris and MPs from polluting the marine environment and translate these observations into predictive models

(3) Characterization of MPs is undertaken using a variety of methods. Standardized collection and identification methods are required to enable better comparison of data and its incorporation in transport and probabilistic risk assessment models.

(4) The majority of studies that have examined MP contamination of biota have focussed on fishes mainly 
belonging to phylum Chordata. There is lack of research on higher order piscine predators, such as tuna and sharks, as well as studies of marine mammals, reptiles, and seabirds. The use of standardized methods for the exposure and analysis of sessile benthic invertebrates such as mussels across the Mediterranean Sea would provide better insight on the abundance and distribution of MPs basin wide.

(5) Currently, one of the big questions is how realistic is it that MPs will be transferred into food webs via contaminated prey under current environmental conditions. Though MP ingestion has been observed in many field-collected organisms, understanding of the intake of MPs through trophic interactions and its long-term effects is limited. Therefore, it is necessary to conduct both laboratory and field studies to understand the consequences of trophic transfer of MP in the Mediterranean region.

(6) There is very limited understanding of the abundance of nanosized plastics in the region. Greater attention should be devoted on the determination of nanosized plastic particles in future studies.

(7) Knowledge of atmospheric transport of MPs in the Mediterranean Sea region is still lacking and needs to be strengthened to improve our understanding of local and regional sources of MPs, especially to the open ocean.

(8) For a better risk assessment of MPs, more research on the levels of metals and trace organic chemicals in/on MPs is required. Knowledge of the impacts of intrinsic and/or extrinsic chemicals are lacking. Addressing the ecotoxicological risks of MP must be focused, considering the effects and interactions of MPs and the chemicals, and, indeed, the microorganisms, they carry.

(9) Last, but not least, while much of the focus on MPs has been in the marine environment, plastic pollution is fundamentally a terrestrial problem. Management strategies to cost-effectively reduce the amount of plastic used, for reducing plastic waste at source, as well as incentives for recycling and improving landfill facilities, need to be identified and implemented by all countries adjacent to the Mediterranean Sea to protect the marine environment

\footnotetext{
Abbreviations

cf:. Compared with; cm: Centimetre; d.w.: Dry weight; CNR: Consiglio Nazionalle delle Recherche; CSIC: Consejo Superior de Investigaciones Científicas; DDT: Dichlorodiphenyltrichloroethane; FAP: Proportion of female authorships; FAOR: Female-to-male authorship odds ratio; FTIR: Fourier Transform Infrared Spectroscopy; g: Gram; IFREMER: Institut Français de Recherche pour I'Exploitation de la Mer; ISPRA: Italian National Institute for Environmental Protection and Research; kg: Kilogram; km: Kilometre; L: Litre; m: Metre; mg: Milligram; mm: Millimetre; MP: Microplastic; ng: Nanogram; org: Organism; PA: Polyamide; PAH: Polycyclic aromatic hydrocarbon; PC: Polycarbide; PCB:
}

Polychlorinated biphenyl; PE: Polyethylene; PET: Polyethylene terephthalate; pg: Picogram; PP: Polypropylene; PS: Polystyrene; PU: Polyurethane; PVC: Polyvinylchloride; RMIT: Royal Melbourne Institute of Technology; um: Micrometre.

\section{Supplementary Information}

The online version contains supplementary material available at https://doi. org/10.1186/s43591-022-00026-2.

Additional file 1.

\section{Acknowledgements}

Not applicable.

\section{Authors' contributions}

All authors contributed to the collection and collation of articles and information extracted therefrom; GA undertook the Citespace analysis; all authors contributed to the writing of the manuscript. The author(s) read and approved the final manuscript.

\section{Authors' information}

Not applicable.

\section{Funding}

We thank the State Government of Victoria for its support of The Plastics Lab through the Port Phillip Bay Fund Round 2 (project PPBF6076).

\section{Availability of data and materials}

All data generated are available in supplementary information files.

\section{Declarations}

\section{Competing interests}

The authors declare that they have no competing interests.

Received: 14 October 2021 Accepted: 18 January 2022

Published online: 22 February 2022

\section{References}

1. Abidli S, Toumi H, Lahbib Y, El Menif TN. The first evaluation of microplastics in sediments from the complex lagoon-channel of Bizerte (Northern Tunisia). Water Air Soil Pollut. 2017;228:262.

2. Abidli S, Antunes JC, Ferreira JL, Lahbib Y, Sobral P, El Menif TN. Microplastics in sediments from the littoral zone of the north Tunisian coast (Mediterranean Sea). Estuar Coast Shelf Sci. 2018;205:1-9.

3. Alomar C, Deudero S. Evidence of microplastic ingestion in the shark Galeus melastomus Rafinesque, 1810 in the continental shelf off the western Mediterranean Sea. Environ Pollut. 2017;223:223-9.

4. Alomar C, Sureda A, Capó X, Guijarro B, Tejada S, Deudero S. Microplastic ingestion by Mullus surmuletus Linnaeus, 1758 fish and its potential for causing oxidative stress. Environ Res. 2017;159:135-42.

5. Alomar C, Estarellas F, Deudero S. Microplastics in the Mediterranean Sea: Deposition in coastal shallow sediments, spatial variation and preferential grain size. Mar Environ Res. 2016;115:1-10.

6. Anastasopoulou A, Viršek MK, Varezic DB, Digka N, Fortibuoni T, Koren $\mathrm{S}$, et al. Assessment on marine litter ingested by fish in the Adriatic and NE Ionian Sea macro-region (Mediterranean). Mar Pollut Bull. 2018:133:841-51.

7. Andrady AL. Microplastics in the marine environment. Mar Pollut Bull. 2011:62(8):1596-605.

8. Artüz ML, Artüz OB, Artüz SD. First report of quantification and classification of buried litter on the public beaches around the Sea of Marmara, Turkey. Marine Pollut Bull. 2021;165:112117.

9. Aryadoust $\mathrm{V}$, Ang BH (2019). Exploring the frontiers of eye tracking research in language studies: a novel co-citation scientometric review. 
Comput Assist Lang Learn https://doi.org/https://doi.org/10.1080/ 09588221.2019.1647251.

10. Avio CG, Gorbi S, Regoli F. Experimental development of a new protocol for extraction and characterization of microplastics in fish tissues: First observations in commercial species from Adriatic Sea. Mar Environ Res. 2015;111:18-26.

11. Avio CG, Gorbi S, Regoli F. Plastics and microplastics in the oceans: From emerging pollutants to emerged threat. Mar Environ Res. 2017;128:2-11.

12. Avio CG, Pittura L, d'Errico G, Abel $S$, Amorello S, Marino G, et al. Distribution and characterization of microplastic particles and textile microfibers in Adriatic food webs: General insights for biomonitoring strategies. Environ Pollut. 2020;258:113766.

13. Axiak V, Bezzina M, Lomax C, Deidun A, Edwards K. First full investigation of levels of microplastics on sandy beaches in Malta. In: Proceedings of the Thirteenth International MEDCOAST Congress on Coastal marine Sciences, Engineering, Management and Conservation, MEDCOAST 2017, 31 October - 04 November 2017, Mellieha. Malta. E.: Özhan (Editor); 2017.

14. Baini M, Fossi MC, Galli M, Caliani I, Campani T, Finoia MG, et al. Abundance and characterization of microplastics in the coastal waters of Tuscany (Italy): The application of the MSFD monitoring protocol in the Mediterranean Sea. Mar Pollut Bull. 2018;133:543-52.

15. Barnes DKA, Galgani F, Thompson RC, Barlaz M. Accumulation and fragmentation of plastic debris in global environments. Phil Trans $R$ Soc B. 2009;364:1985-98.

16. Battaglia P, Pedà C, Musolino S, Esposito V, Andaloro F, Romeo T. Diet and first documented data on plastic ingestion of Trachinotus ovatus $L$. 1758 (Pisces: Carangidae) from the Strait of Messina (central Mediterranean Sea). Italian Journal of Zoology. 2016;83(1):121-9.

17. Battaglia FM, Beckingham BA, Mcfee WE. First report from North America of microplastics in the gastrointestinal tract of stranded bottlenose dolphins (Tursiops truncatus). Mar Pollut Bull. 2020;160:111677.

18. Bellas J, Martínez-Armental J, Martínez-Cámara A, Besada V, MartínezGómez C. Ingestion of microplastics by demersal fish from the Spanish Atlantic and Mediterranean coasts. Mar Pollut Bull. 2016;109:55-60.

19. Bendels MHK, Muèller R, Brueggmann D, Groneberg DA. Gender disparities in high- quality research revealed by Nature Index journals. PLoS One. 2018;13(1):e0189136.

20. Berov D, Klayn S. Microplastics and floating litter pollution in Bulgarian Black Sea coastal waters. Mar Pollut Bull. 2020;156:111225.

21. Besley A, Vijver MG, Behrens P, Bosker T. A standardized method for sampling and extraction methods for quantifying microplastics in beach sand. Mar Pollut Bull. 2017;114:77-83.

22. Bianchi J, Valente T, Scacco U, Cimmaruta R, Sbrana A, Silvestri $C$, et al. Food preference determines the best suitable digestion protocol for analysing microplastic ingestion by fish. Mar Pollut Bull. 2020;154:111050.

23. Blašković A, Fastelli P, Čižmek H, Guerranti C, Renzi M. Plastic litter in sediments from the Croatian marine protected area of the natural park of Telaščica bay (Adriatic Sea). Mar Pollut Bull. 2017;1 14:583-6.

24. Blašković A, Guerranti C, Fastelli P, Anselmi S, Renzi M. Plastic levels in sediments closed to Cecina river estuary (Tuscany, Italy). Mar Pollut Bull. 2018:135:105-9.

25. Boerger C, Lattin G, Moore SL, Moore CJ. Plastic ingestion by planktivorous fishes in the North Pacific Central Gyre. Mar Pollut Bull. 2010;60(12):2275-8.

26. Bottari T, Savoca S, Mancuso M, Capillo G, Panarello G, MartinaBonsignore $\mathrm{M}$, et al. Plastics occurrence in the gastrointestinal tract of Zeus faber and Lepidopus caudatus from the Tyrrhenian Sea. Mar Pollut Bull. 2019;146:408-16.

27. Boucher J, Bilard G. The Mediterranean: Mare plasticum. Gland: IUCN $x+62 p ; 2020$

28. Bråte ILN, Blázquez M, Brooks SJ, Thomas KV. Weathering impacts the uptake of polyethylene microparticles from toothpaste in Mediterranean mussels (M. galloprovincialis). Sci Total Environ. 2018;626:1310-8.

29. Browne MA, Crump P, Niven SJ, Teuten E, Tonkin A, Galloway T, et al. Accumulation of microplastic on shorelines worldwide: sources and sinks. Environ Sci Technol. 2011;45:9175-9.

30. Caldwell J, Petri-Fink A, Rothen-Rutishauser B, Lehner R. Assessing meso- and microplastic pollution in the Ligurian and Tyrrhenian Seas. Mar Pollut Bull. 2019;149:110572.
31. Caldwell J, Muff LF, Pham CK, Petri-Fink A, Rothen-Rutishauser B, Lehner R. Spatial and temporal analysis of meso- and microplastic pollution in the Ligurian and Tyrrhenian Seas. Mar Pollut Bull. 2020;159:111515

32. Camins E, de Haan WP, Salvo V-S, Canals M, Raffard A, Sanchez-Vidal A. Paddle surfing for science on microplastic pollution. Sci Total Environ. 2020;709:136178.

33. Cannas S, Fastelli P, Guerranti C, Renzi M. Plastic litter in sediments from the coasts of south Tuscany (Tyrrhenian Sea). Mar Pollut Bull. 2017;119:372-5.

34. Capillo G, Savoca S, Panarello G, Mancuso M, Branca C, Romano V, et al. Quali-quantitative analysis of plastics and synthetic microfibers found in demersal species from Southern Tyrrhenian Sea (Central Mediterranean). Mar Pollut Bull. 2020;150:110596.

35. Capo X, Rubio M, Solomando A, Alomar C, Compa M, Sureda A, et al. Microplastic intake and enzymatic responses in Mytilus galloprovincialis reared at the vicinities of an aquaculture station. Chemosphere. 2021;280:130575.

36. Capriotti M, Cocci P, Bracchetti L, Cottone E, Scandiffio R, Caprioli G, et al. Microplastics and their associated organic pollutants from the coastal waters of the central Adriatic Sea (Italy): Investigation of adipogenic effects in vitro. Chemosphere. 2021;263:128090.

37. Carpenter EJ, Smith KL. Plastics on the Sargasso Sea surface. Science. 1972:175:1240-1.

38. Carson HS, Colbert SL, Kaylor MJ, Mcdermid KJ. Small plastic debris changes water movement and heat transfer through beach sediments. Mar Pollut Bull. 2011;62:1708-13.

39. Cau A, Avio CG, Dessì C, Follesa MC, Moccia D, Regoli F, et al. Microplastics in the crustaceans Nephrops norvegicus and Aristeus antennatus: Flagship species for deep-sea environments? Environ Pollut. 2019;255:113107.

40. Chen C. CiteSpace II: Detecting and Visualizing Emerging Trends and Transient Patterns in Scientific Literature. J Am Soc Inf Sci Technol. 2006;57:359-77.

41. Chen $X$, Liu Y. Visualization analysis of high-speed railway research based on CiteSpace. Transp Policy. 2020;85:1-17. https://doi.org/10. 1016/j.tranpol.2019.10.004.

42. Chen C, Chen Y, Horowitz M, Hou H, Liu Z, Pellegrino D. Towards an explanatory and computational theory of scientific discovery. J Inf Secur. 2009:3:191-209.

43. Chen C, Ibekwe-sanjuan F, Hou J. The structure and dynamics of cocitation clusters: A multiple-perspective cocitation analysis. J Am Soc Inf Sci Technol. 2010;61:1386-409.

44. Chen C. CiteSpace: A Practical Guide for Mapping Scientific Literature. Incorporated, New York: Nova Science Publishers; 2016.

45. Chen Y, Awasthi AK, Wei F, Tan Q Li J. Single-use plastics: Production, usage, disposal, and adverse impacts. Sci Total Environ. 2021;752:141772.

46. Cincinelli A, Martellini T, Guerranti C, Scopetani C, Chelazzi D, Giarrizzo T. A potpourri of microplastics in the sea surface and water column of the Mediterranean Sea. Trends Anal Chem. 2019;110:321-6.

47. Cincinelli A, Scopetani C, Chelazzi D, Martellini T, Pogojeva M, Slobodnik J. Microplastics in the Black Sea sediments. Sci Total Environ. 2021;760:143898

48. Claessens M, De Meester S, Van Landuyt L, De Clerck K, Janssen CR. Occurrence and distribution of microplastics in marine sediments along the Belgian coast. Mar Pollut Bull. 2011;62(10):2199-204.

49. Codina-García M, Militão T, Moreno J, González-Solís J. Plastic debris in Mediterranean seabirds. Mar Pollut Bull. 2013;77:220-6.

50. Collard F, Gilbert B, Compère P, Eppe G, Das K, Jauniaux T, et al. Microplastics in livers of European anchovies (Engraulis encrasicolus, L.). Environ Pollut. 2017;229:1000-5.

51. Collignon A, Hecq J-H, Galgani F, Voisin P, Collard F, Goffart A. Neustonic microplastic and zooplankton in the North Western Mediterranean Sea. Mar Pollut Bull. 2012;64(4):861-4.

52. Collignon A, Hecq J-H, Galgani F, Collard F, Goffart A. Annual variation in neustonic micro- and meso-plastic particles and zooplankton in the Bay of Calvi (Mediterranean-Corsica). Mar Pollut Bull. 2014;79:293-8

53. Compa M, Ventero A, Iglesias M, Deudero S. Ingestion of microplastics and natural fibres in Sardina pilchardus (Walbaum, 1792) and 
Engraulis encrasicolus (Linnaeus, 1758) along the Spanish Mediterranean coast. Mar Pollut Bull. 2018;128:89-96.

54. Constant M, Kerhervé P, Mino-Vercellio-Verollet M, Dumontier M, Sànchez Vidal A, Canals M, et al. Beached microplastics in the Northwestern Mediterranean Sea. Mar Pollut Bull. 2019;142:263-73.

55. Cozar A, Sanz-Martin M, Marti E, Gonzalez-Gordillo JI, Ubeda B, Galvez $J A$, et al. Plastic accumulation in the Mediterranean sea. PLoS One. 2015;10:e0121762.

56. Çullu AF, Sönmez VZ, Sivri N. Microplastic contamination in surface waters of the Küçükçekmece Lagoon, Marmara Sea (Turkey): Sources and areal distribution. Environ Pollut. 2021;268:115801.

57. Dahl M, Bergman S, Bjork M, Diaz-Almela E, Granberg M, Gullstrom M, et al. A temporal record of microplastic pollution in Mediterranean seagrass soils. Environ Pollut. 2021;272:116451.

58. de Haan W.P., Sanchez-Vidal A., Canals M., NUREIEV1 Shipboard Scientific Party (2019). Floating microplastics and aggregate formation in the Western Mediterranean Sea. Mar Pollut Bull 140: 523-535.

59. De Ruijter V, Milou A, Costa V. Assessment of microplastics distribution and stratification in the shallow marine sediments of Samos island, Eastern Mediterranean sea. Greece Mediterr Mar Sci. 2019;20:736-44.

60. Di Renzo L, Mascilongo G, Berti M, Bogdanović T, Listeš E, Brkljača M, et al. Potential Impact of Microplastics and Additives on the Health Status of Loggerhead Turtles (Caretta caretta) Stranded Along the Central Adriatic Coast. Water, Air Soil Pollution. 2021;232:98.

61. Digka N, Tsangaris C, Torre M, Anastasopoulou A, Zeri C. Microplastics in mussels and fish from the Northern Ionian Sea. Mar Pollut Bull. 2018;135:30-40.

62. Duncan EM, Arrowsmith J, Bain C, Broderick AC, Lee J, Metcalfe K, et al. The true depth of the Mediterranean plastic problem: Extreme microplastic pollution on marine turtle nesting beaches in Cyprus. Mar Pollut Bull. 2018;136:334-40.

63. Dunning T. Accurate methods for the Statistics of Surprise and Coincidence. Comput Linguist. 1993;19:61-74.

64. Ehlers SM, Ellrich JA. First record of 'plasticrusts' and 'pyroplastic' from the Mediterranean Sea. Mar Pollut Bull. 2020;151:110845.

65. Eriksen M, Lebreton LCM, Carson HS, Thiel M, Moore CJ, Borerro JC, et al. Plastic Pollution in the World's Oceans: More than 5 Trillion Plastic Pieces Weighing over 250,000 Tons Afloat at Sea. PLoS One. 2014;9(12):e111913.

66. Everaert G, De Rijcke M, Lonneville B, Janssen CR, Backhaus T, Mees J, et al. Risks of floating microplastic in the global ocean. Environ Pollut. 2020;267:115499

67. Expósito N, Joaquim Rovira J, Jordi Sierra J, Folch J, Schuhmacher M. Microplastics levels, size, morphology and composition in marine water, sediments and sand beaches. Case study of Tarragona coast (western Mediterranean). Sci Total Environ. 2021;786:147453.

68. Fastelli P, Blašković A, Bernardi G, Romeo T, Čižmek H, Andaloro F, et al. Plastic litter in sediments from a marine area likely to become protected (Aeolian Archipelago's islands, Tyrrhenian sea). Mar Pollut Bull. 2016;113:526-9.

69. Faure F, Saini C, Potter G, Galgani F, Alencastro L, Hagmann P. An evaluation of surface micro- and mesoplastic pollution in pelagic ecosystems of the Western Mediterranean Sea. Environ Sci Pollut Res. 2015;22:12190-7.

70. Filgueiras AV, Gago J, Campillo JA, León VM. Microplastic distribution in surface sediments along the Spanish Mediterranean continental shelf. Environ Sci Pollut Res. 2019;26(21):21264-73.

71. Filgueiras AV, Preciado I, Cartón A, Gago J. Microplastic ingestion by pelagic and benthic fish and diet composition: A case study in the NW Iberian shelf. Mar Pollut Bull. 2020;160:111623.

72. Fossi MC, Panti C, Guerranti C, Coppola D, Giannetti M, Marsili L, et al. Are baleen whales exposed to the threat of microplastics? A case study of the Mediterranean fin whale (Balaenoptera physalus). Mar Pollut Bull. 2012;64(11):2374-9.

73. Fossi MC, Marsili L, Baini M, Giannetti M, Coppola D, Guerranti C, et al. Fin whales and microplastics: The Mediterranean Sea and the Sea of Cortez scenarios. Environ Pollut. 2016;209:68-78.

74. Freeman LC (1977). A set of measures of centrality based on betweenness. Sociometry 40(1): 35-41. https://doi.org/https://doi.org/10.2307/ 3033543
75. Galgani F, Hanke G, Werner S, De Vrees L. Marine litter within the European Marine Strategy Framework Directive. ICES J Mar Sci. 2013;70(6):1055-64

76. Garcia-Garin O, Vighi M, Aguilar A, Tsangaris C, Digka N, Kaberi H, et al. Boops boops as a bioindicator of microplastic pollution along the Spanish Catalan coast. Mar Pollut Bull. 2019;149:110648.

77. Gajšt T, Bizjak T, Palatinus A, Liubartseva S, Kržan A. Sea surface microplastics in Slovenian part of the Northern Adriatic. Mar Pollut Bull. 2016:113:392-9.

78. Giani D, Baini M, Galli M, Casini S, Fossi MC. Microplastics occurrence in edible fish species (Mullus barbatus and Merluccius merluccius) collected in three different geographical sub-areas of the Mediterranean Sea. Mar Pollut Bull. 2019;140:129-37.

79. Godoy V, Prata JC, Blázquez G, Almendros Al, Duarte AC, Rocha-Santos $T$, et al. Effects of distance to the sea and geomorphological characteristics on the quantity and distribution of microplastics in beach sediments of Granada (Spain). Sci Total Environ. 2020;746:142023.

80. Gonçalves C, Martins M, Sobral P, Costa PM, Costa MH. An assessment of the ability to ingest and excrete microplastics by filter-feeders: A case study with the Mediterranean mussel. Environ Pollut. 2019;245:600-6.

81. Guerranti C, Cannas S, Scopetani C, Fastelli P, Cincinelli A, Renzi M. Plastic litter in aquatic environments of Maremma Regional Park (Tyrrhenian Sea, Italy): Contribution by the Ombrone river and levels in marine sediments. Mar Pollut Bull. 2017;117:366-70.

82. Gündoğdu S. High level of micro-plastic pollution in the Iskenderun Bay NE Levantine coast of Turkey. Ege J Fisheries Aquatic Sci. 2017;34:401-8.

83. Gündoğdu S, Çevik C, Ayat B, Aydoğan B, Karaca S. How microplastics quantities increase with flood events? An example from Mersin Bay NE Levantine coast of Turkey. Environ Pollut. 2018;239:342-50.

84. Guo X, Wang J. The chemical behaviors of microplastics in marine environment: A review. Mar Pollut Bull. 2019:142:1-14.

85. Güven O, Gökdağ K, Jovanović B, Kıdeyş AE. Microplastic litter composition of the Turkish territorial waters of the Mediterranean Sea, and its occurrence in the gastrointestinal tract of fish. Environ Pollut. 2017;223:286-94.

86. Hays H, Cormons G. Plastic particles found in Tern pellets, on coastal beaches and at factory sites. Mar Pollut Bull. 1974;5:44-6.

87. Hernandez-Gonzalez A, Saavedra C, Gago J, Covelo P, Santos MB, Pierce GJ. Microplastics in the stomach contents of common dolphin (Delphinus delphis) stranded on the Galician coasts (NW Spain, 2005-2010). Mar Pollut Bull. 2018;137:526-32.

88. Hidalgo-Ruz V, Gutow L, Thompson RC, Thiel M. Microplastics in the marine environment: A review of the methods used for identification and quantification. Environ Sci Technol. 2012:46:3060-75.

89. Jambeck JR, Geyer R, Wilcox C, Siegler TR, Perryman M, Andrady $A$, et al. Plastic waste inputs from land into the ocean. Science. 2015;347:768-71.

90. Karapanagioti HK, Endo S, Ogata Y, Takada H. Diffuse pollution by persistent organic pollutants as measured in plastic pellets sampled from various beaches in Greece. Mar Pollut Bull. 2011;62:312-7.

91. Kazour M, Jemaa S, Issa C, Khalaf G, Amara R. Microplastics pollution along the Lebanese coast (Eastern Mediterranean Basin): Occurrence in surface water, sediments and biota samples. Sci Total Environ. 2019;696:133933.

92. Kleinberg J. Bursty and hierarchical structure in streams. Proc. ACM SIGKDD Int. Conf Knowl Discov Data Min. 2002;7:373-97.

93. Korez $\breve{S}$, Gutow L, Saborowski R. Microplastics at the strandlines of Slovenian beaches. Mar Pollut Bull. 2019:145:334-42.

94. Krüger L, Casado-Coy N, Valle C, Ramos M, Sánchez-Jerez P, Gago J, et al. Plastic debris accumulation in the seabed derived from coastal fish farming. Environ Pollut. 2020;257:113336.

95. Kukulka T, Proskurowski G, Morét-Ferguson S, Meyer DW, Law KL. The effect of wind mixing on the vertical distribution of buoyant plastic debris. Geophys Res Lett. 2012;39:L07601.

96. Kutralam-Muniasamy G, Pérez-Guevara F, I Elizalde-Martínez I, Shruti VC. Review of current trends, advances and analytical challenges for microplastics contamination in Latin America. Environ Pollut. 2020;267:115463.

97. Laglbauer BJL, Franco-Santos RM, Andreu-Cazenave M, Brunelli L, Papadatou M, Palatinus $A$, et al. Macrodebris and microplastics from beaches in Slovenia. Mar Pollut Bull. 2014;89:356-66. 
98. Lakshmi Kavya ANV, Sundarrajan S, Ramakrishna S. Identification and characterization of micro-plastics in the marine environment: A mini review. Mar Pollut Bull. 2020;160:111704.

99. Lebreton LCM, Greer SD, Borrero JC. Numerical modelling of floating debris in the world's oceans. Mar Pollut Bull. 2012;64:653-61.

100. Lefebvre C, Saraux C, Heitz O, Nowaczyk A, Bonnet D. Microplastics FTIR characterisation and distribution in the water column and digestive tracts of small pelagic fish in the Gulf of Lions. Mar Pollut Bull. 2019:142:510-9.

101. Liu W, Zhang J, Hang Liu H, Guo X, Zhang X, Yao X, et al. A review of the removal of microplastics in global wastewater treatment plants: Characteristics and mechanisms. Environ Int. 2021;146:106277.

102. Löder MGJ, Gerdts G. Methodology used for the detection and identification of microplastics - A critical appraisal. In: Bergmann M, Gutow L, Klages M, editors. Marine Anthropogenic Litter. Cham: Springer International Publishing; 2015

103. Lots FAE, Behrens P, Vijver MG, Horton AA, Bosker T. A large-scale investigation of microplastic contamination: Abundance and characteristics of microplastics in European beach sediment. Mar Pollut Bull. 2017:123:219-26.

104. Liubartseva S, Coppini G, Lecci R, Creti S. Regional approach to modeling the transport of floating plastic debris in the Adriatic Sea. Mar Pollut Bull. 2016;103:115-27.

105. Mancuso M, Savoca S Bottari T (2019). First record of microplastics ingestion by European hake Merluccius merluccius from the Tyrrhenian Sicilian coast (Central Mediterranean Sea). J Fish Biol 94: 517-519.

106. Messinetti S, Mercurio S, Parolini M, Sugni M, Pennati R. Effects of polystyrene microplastics on early stages of two marine invertebrates with different feeding strategies. Environ Pollut. 2018;237:1080-7.

107. Missawi O, Bousserrhine N, Belbekhouche S, Zitouni N, Alphonse V, Boughattas I, et al. Abundance and distribution of small microplastics $(\leq 3 \mu \mathrm{m})$ in sediments and seaworms from the Southern Mediterranean coasts and characterisation of their potential harmful effects. Environ Pollut. 2020;263:114634.

108. Moore CJ, Moore SL, Leecaster MK, Weisberg SB. A comparison of plastic and plankton in the North Pacific Central Gyre. Mar Pollut Bull. 2001;42(12):1297-300

109. Morét-Ferguson S, Law KL, Proskurowski G, Murphy EK, Peacock EE, Reddy CM. The size, mass, and composition of plastic debris in the western North Atlantic Ocean. Mar Pollut Bull. 2010:60(10):1873-8.

110. Morris RJ. Floating plastic debris in the Mediterranean. Mar Pollut Bull. 1980:11(5):125.

111. Nadal MA, Alomar C, Deudero S. High levels of microplastic ingestion by the semipelagic fish bogue Boops boops (L.) around the Balearic Islands. Environ Pollut. 2016;214:517-23.

112. Newman MEJ. Modularity and community structure in networks. Proc Natl Acad Sci U S A. 2006;103:8577-82.

113. Novillo O, Raga JA, Tomás J. Evaluating the presence of microplastics in striped dolphins (Stenella coeruleoalba) stranded in the Western Mediterranean Sea. Mar Pollut Bull. 2020;160:111557.

114. Oztekin A, Bat L. Microlitter pollution in sea water: a preliminary study from Sinop Sarikum coast of the southern Black Sea. Turkish J Fish Aquatic Sci. 2017:17:1431-40.

115. Palatinus A, Viršek KM, Robič U, Grego M, Bajt O, Šiljí J, et al. Marine litter in the Croatian part of the middle Adriatic Sea: Simultaneous assessment of floating and seabed macro and micro litter abundance and composition. Mar Pollut Bull. 2019:139:427-39.

116. Pellini G, Gomiero A, Fortibuoni T, Ferrà C, Grati F, Tassetti AN, et al. Characterization of microplastic litter in the gastrointestinal tract of Solea solea from the Adriatic Sea. Environ Pollut. 2018:234:943-52.

117. Pennino MG, Bachiller E, Lloret-Lloret E, Albo-Puigserver M, Esteban A, Jadaud $A$, et al. Ingestion of microplastics and occurrence of parasite association in Mediterranean anchovy and sardine. Mar Pollut Bull. 2020:158:111399.

118. Piperagkas O, Papageorgiou N, Karakassis I. Qualitative and quantitative assessment of microplastics in three sandy Mediterranean beaches, including different methodological approaches. Estuar Coast Shelf Sci. 2019:219:169-75

119. Renzi M, Blašković A. Chemical fingerprint of plastic litter in sediments and holothurians from Croatia: Assessment \& relation to different environmental factors. Mar Pollut Bull. 2020:153:110994.
120. Renzi M, Blašković A, Fastelli P, Marcelli M, Guerranti C, Cannas S, et al. Is the microplastic selective according to the habitat? Records in amphioxus sands, Mäerl bed habitats and Cymodocea nodosa habitats. Mar Pollut Bull. 2018;130:179-83.

121. Renzi M, Specchiulli A, Blašković A, Manzo C, Mancinelli G, Cilenti L. Marine litter in stomach content of small pelagic fishes from the Adriatic Sea: sardines (Sardina pilchardus) and anchovies (Engraulis encrasicolus). Environ Sci Pollut Res. 2019;26:2771-81.

122. Renzi M, Blašković A, Broccoli A, Bernardi G, Grazioli E, Russo G. Chemical composition of microplastic in sediments and protected detritivores from different marine habitats (Salina Island). Mar Pollut Bull. 2020;152:110918.

123. Rios-Fuster B, Alomar C, Compa M, Guijarro B, Deudero S. Anthropogenic particles ingestion in fish species from two areas of the. western Mediterranean Sea. Mar Pollut Bull. 2019;144:325-33.

124. Rochman CM, Hoh E, Hentschel BT, Kaye S. Long-term field measurement of sorption of organic contaminants to five types of plastic pellets: Implications for plastic marine debris. Environ Sci Technol. 2013;47:1646-54.

125. Romeo T, Pietro B, Pedà C, Consoli P, Andaloro F, Fossi MC. First evidence of presence of plastic debris in stomach of large pelagic fish in the Mediterranean Sea. Mar Pollut Bull. 2015;95:358-61.

126. Romeo T, Pedà C, MC F, Andaloro F, Battaglia P. First record of plastic debris in the stomach of Mediterranean lanternfishes. Acta Adriat. 2016:57(1):115-24.

127. Rousseeuw PJ. Silhouettes: A graphical aid to the interpretation and validation of cluster analysis. J Comput Appl Math. 1987;20:53-65.

128. Ruiz-Orejón LF, Sardá R, Ramis-Pujol J. Now, you see me: High concentrations of floating plastic debris in the coastal waters of the Balearic Islands (Spain). Mar Pollut Bull. 2018;133:636-46.

129. Ruiz-Orejón LF, Mourre B, Sardá R, Tintoré J, Ramis-Pujol J. Quarterly variability of floating plastic debris in the marine protected area of the Menorca Channel (Spain). Environ Pollut. 2019;252:1742-54.

130. Savinelli B, NM FTVG, D'Anna G, Pipitone C, Prada F, Zenone A, et al. Microplastics impair the feeding performance of a Mediterranean habitat-forming coral. Mar Environ Res. 2020;155:104887.

131. Savoca S, Capillo G, Mancuso M, Bottari T, Crupi R, Branca C, et al. Microplastics occurrence in the Tyrrhenian waters and in the gastrointestinal tract of two congener species of seabreams. Environ Toxicol Pharmacol. 2019;67:35-41

132. Savoca S, Bottari T, Fazio E, Bonsignore M, Mancuso M, Luna GM, et al. Plastics occurrence in juveniles of Engraulis encrasicolus and Sardina pilchardus in the Southern Tyrrhenian Sea. Sci Total Environ. 2020;718:137457.

133. Sbrana A, Valente T, Scacco U, Bianchi J, Silvestri C, Palazzo L, de Lucia GA, Valerani C, Ardizzone G, Matiddi M. Spatial variability and influence of biological parameters on microplastic ingestion by Boops boops (L.) along the Italian coasts (Western Mediterranean Sea). Environ Pollut. 2020;263:114429.

134. Schirinzi GF, Pedà C, Battaglia P, Laface F, Galli M, Baini M, Consoli P, Scotti G, Esposito V, Faggio C, Farré M, Barceló D, Fossi MC, Andaloro F, Romeo T. A new digestion approach for the extraction of microplastics from gastrointestinal tracts (GITs) of the common dolphinfish (Coryphaena hippurus) from the western Mediterranean Sea. J Hazard Mater. 2020:397:122794

135. Schmidt N, Thibault D, Galgani F, Paluselli A, Sempéré R. Occurrence of microplastics in surface waters of the Gulf of Lion (NW Mediterranean Sea). Prog Oceanogr. 2018;163:214-20.

136. Sener M, Doğruyol P, Balkaya N. Microplastic pollution in the Black Sea Coast of the Anatolian side of Istanbul, Turkey. Desalin Water Treat. 2019;172:351-8.

137. Shiber JG. Plastic pellets on the coast of Lebanon. Mar Pollut Bull. 1979;10:28-30.

138. Small H. Co-citation in the scientific literature: A new measure of the relationship between two documents. J Am Soc Inf Sci. 1973;24:265-9.

139. Simon-Sánchez L, Grelaud M, Garcia-Orellana J, Ziveri P. River Deltas as hotspots of microplastic accumulation: The case study of the Ebro River (NW Mediterranean). Sci Total Environ. 2019:687:1186-96.

140. Statista (2020). Statistics and facts about the global plastics industry. https://www.statista.com/topics/5266/plastics-industry/ Last access: $10 / 08 / 21$ 
141. Suaria G, Avio CG, Mineo A, Lattin GL, Magaldi MG, Belmonte G, et al. The Mediterranean Plastic Soup: synthetic polymers in Mediterranean surface waters. Sci Rep. 2016;6:37551.

142. Tata T, Belabed BE, Bououdina M, Bellucci S. Occurrence and characterization of surface sediment microplastics and litter from North African coasts of Mediterranean Sea: Preliminary research and first evidence. Sci Total Environ. 2020;713:136664.

143. Teuten EL, Rowland SJ, Galloway TS, Thompson RC. Potential for plastics to transport hydrophobic contaminants. Environ Sci Technol. 2007:41:7759-64.

144. Tsangaris C, Digka N, Valente T, Aguilar A, Borrell A, de Lucia GA, et al. Using Boops boops (osteichthyes) to assess microplastic ingestion in the Mediterranean Sea. Mar Pollut Bull. 2020;158:111397.

145. Turner A, Luke Holmes L. Occurrence, distribution and characteristics of beached plastic production pellets on the island of Malta (central Mediterranean). Mar Pollut Bull. 2011;62:377-81.

146. Tziourrou P, Megalovasilis P, Tsounia M, Karapanagioti HK. Characteristics of microplastics on two beaches affected by different land uses in Salamina Island in Saronikos Gulf, east Mediterranean. Mar Pollut Bull. 2019;149:110531.

147. United Nations (2014). Country classifications. Available online. Last accessed 5/11/20; https://www.un.org/en/development/desa/policy/ wesp/wesp_current/2014wesp_country_classification.pdf

148. Valente T, Sbrana A, Scacco U, Jacomini C, Bianchi J, Palazzo L, et al. Exploring microplastic ingestion by three deep-water elasmobranch species: A case study from the Tyrrhenian Sea. Environ Pollut. 2019:253:342-50.

149. Van Cauwenberghe L, Vanreusel A, Mees J, Janssen CR. Microplastic pollution in deep sea sediments. Environ Pollut. 2013;182:495-9.

150. van der Hal N, Ariel A, Angel DL. Exceptionally high abundances of microplastics in the oligotrophic Israeli Mediterranean coastal waters. Mar Pollut Bull. 2017;116:151-5.

151. Vianello A, Boldrin A, Guerriero P, Moschino V, Rella R, Sturaro A, et al. Microplastic particles in sediments of Lagoon of Venice, Italy: First observations on occurrence, spatial patterns and identification. Estuar Coast Shelf Sci. 2013;130:54-61.

152. Vianello A, Ros L, Boldrin A, Marceta T, Moschino V. First evaluation of floating microplastics in the Northwestern Adriatic Sea. Environ Sci Pollut Res. 2018;25:28546-61.

153. Viršek MK, Lovšin MN, Koren S, Kržan A, Peterlin M. Microplastics as a vector for the transport of the bacterial fish pathogen species Aeromonas salmonicida. Mar Pollut Bull. 2017;125:301-9.

154. Wang M, Liu P, Zhang R, Li Z, Li X. A scientometric analysis of global health research. Int J Environ Res Public Health. 2020;17:2963.

155. Woodall LC, Sanchez-Vidal A, Canals M, Paterson GLJ, Coppock R, Sleight $\mathrm{V}$, et al. The deep sea is a major sink for microplastic debris. $\mathrm{R}$ Soc Open Sci. 2014;1:140317.

156. Yabanli M, Yozukmaz A, Şener I, Ölmez ÖT. Microplastic pollution at the intersection of the Aegean and Mediterranean Seas: A study of the Datça Peninsula (Turkey). Mar Pollut Bull. 2019;145:47-55.

\section{Publisher's Note}

Springer Nature remains neutral with regard to jurisdictional claims in published maps and institutional affiliations.

\section{Submit your manuscript to a SpringerOpen ${ }^{\circ}$ journal and benefit from:}

- Convenient online submission

- Rigorous peer review

- Open access: articles freely available online

- High visibility within the field

- Retaining the copyright to your article 